\title{
Træk af den arkitekturhistoriske udvikling i det tidligere Åbenrå- Sønderborg amt ca. 1750-1820
}

\author{
Af Jesper Tofft
}

\section{Indledning}

Sønderjylland er ikke en egn, der er præget af store og fornemme byggerier $\mathrm{i}$ form af slotte og herregårde, således som f.eks. Fyn er det. Men landsdelen har alligevel $i$ perioder haft en særegen og forfinet bygningskultur i en mindre imposant målestok. Den har især omfattet mindre byggerier som borgerhuse, gårde og præstegårde, og kun få større anlæg som slotte og herregårde. Især to sønderjysk-slesvigske egne markerer sig i denne sammenhæng, nemlig Åbenrå-Sønderborgområdet og de frisisk påvirkede marskegne.

Særlig bemærkelsesværdig var bygningskulturen i den periode, som vi i denne artikel vil se nærmere på, nemlig de 70 år mellem $1750 \mathrm{og}$ 1820. Vi vil koncentrere os om Åbenrå-Sønderborg-egnen (det tidligere Åbenrå-Sønderborg Amt, incl. Als), fordi der her viser sig et interessant mønster i den bygningshistoriske stiludvikling. Samtidig er denne periodes byggerier at henregne til egnens fornemste i det hele taget.

Det mønster, der er tale om, er til en vis grad knyttet til 3 bygmestre, der efter hinanden var ansat som hertugelige bygmestre hos hertugen af Augustenborg. De har hver deres personlige og deres tids særpræg, som lader sig følge $\mathrm{i}$ deres byggerier for hertughoffet og for hele områdets rigeste og mest betydningsfulde folk.

Perioden, vi arbejder med, udgøres stilmæssigt af overgangen fra senbarok og rokoko til nyklassicisme, også kaldet Louis Seize-stil. Som ofte $\mathrm{i}$ provinsen, er der også her tale om en - ihvertfald delvis "stilforsinkelse $\mathrm{i}$ forhold til f.eks. de store byer. Et eksempel kunne være, at man på denne egn finder hoveddøre $\mathrm{i}$ rokoko helt op $\mathrm{i}$ 1780'erne, hvor de andre steder for længst var gået af mode. Sydpå i de vestholstenske egne, var stilforsinkelsen dog endnu mere udpræget.

Som nævnt vil vi her følge 3 hofbygmestre og deres byggerier, men i virkeligheden er det kun ret få bygninger, hvorom vi med sikkerhed 
kan sige, hvem der har stået som ophavsmand. Resten af husene må vi forsøge at tilskrive bygmestrene i det omfang, det synes forsvarligt.

De 3 bygmestre eller arkitekter var Lorentz Jacobsen (1721-79), Christian August Bohlsmann (1740-94) og Jürgen Christian Bleshøy (1773-1826). De to første var uddannet som murer og tømrer, men har formentlig ikke gået på noget akademi. Det udelukker dog ikke, at de har videre-uddannet sig på forskellig vis, både ved selvstudier og ved samarbejde med »rigtige« arkitekter. Om Bleshøy ved vi imidlertid, at han blev videreuddannet hos den store danske arkitekt C. F. Hansen, da denne arbejdede i Altona. Vi vil derfor fremover kalde dem bygmestre og ikke arkitekter, da de mere har deres rod i en håndværksmæssig end $i$ en akademisk tradition.

I det følgende vil bygningshistorien blive gennemgået ved hjælp af simpel sammenlignende stilanalyse sammenholdt med litterære og arkivalske kilder. Analysen underbygges af ca. 50 konkrete bygningsværker, der er opstillet $\mathrm{i}$ tabellen. Afhandlingen her er kaldt træk af den arkitekturhistoriske udvikling, da den ikke foregiver at beskrive hele udviklingen, men kun en del af den. Modsætningen går i særlig grad mellem landlig bygningskultur og borgerlig bygningskultur. Og det er den borgerlige stil, vi her vil følge ved hjælp af en række endnu eksisterende huse fra perioden fra omkring 1750 til omkring 1820. De i tabellen opstillede bygninger skal ikke forestille en komplet registrant, men er blandt de mest typiske og velbevarede eksempler. Andre huse fra tiden er nedrevet, brændt eller ombygget $i$ en sådan grad, at de ikke umiddelbart kan indpasses i analysen. (Se tabellen s. 125-26).

M.h.t. den foreliggende litteratur til emnet kan siges, at der er skrevet en del om enkelte bygningstyper som præstegårde, borgerhuse og slotte. Men der er ikke tidligere foretaget en overordnet stilanalyse omfattende alle bygningstyper over en længere periode, og over et større område, sådan som det her vil blive forsøgt.

\section{Rokokoen}

Frem til midten af 1770 'erne var det stadig senbarok og rokoko, der prægede det finere byggeri. Byhusene blev, hvad enten det var langhuse eller gavlhuse, udsmykket med fine detaljer omkring indgangspartiet og $\mathrm{i}$ facaden $\mathrm{i}$ det hele taget. Indgangspartiet er ofte indrammet af en profileret pilasterportal med en volutomkranset hustavle (mindeplade) ovenover. Døren er typisk trukket lidt ind og rundbuet. Selve dørfløjene er ofte udskåret med rocaille-ornamenter ligesom det lille overvindue (se f.eks. fig. 3 og 8). 
I disse år finder vi i Åbenrå bygmesteren Lorentz Jacobsen (172179). Han var født i Stubbæk, Ensted Sogn den 6. februar 1721 som søn af Jacob Lorentzen. ${ }^{1}$ I 1745 den 8 . januar fik han borgerskab $i$ Åbenrå som murersvend, og samme år den 13. september giftede han sig for første gang med Maria Christensen. ${ }^{2}$

Han må imidlertid snart have etableret sig som mester, for allerede i 1747 finder vi ham i Kliplev, hvor han bygger den smukke præstegård for pastor Peter Breckling. ${ }^{3}$ Han må have været en meget dygtig mand, når han som kun 26-årig blev hidkaldt for at bygge præstegården. Den er et elegant og velproportioneret bygningsværk. Særligt bemærkes pilasterportalen med volutbåret segmentbue over. Ligeledes er vinduerne præget af fine detaljer. Som i andre af tidens bygninger, ses også her de typiske liljeformede murankre.

Denne oplysning har vi sammen med flere andre fra en interessant notits i Ensted kirkebog, hvor det afsløres, at han foruden præstegården i Kliplev, også byggede Skovbølgård, Ballegård, slotskirken på Augustenborg og en del af slottet.4

Ifølge Steensberg er Mørks Kro i Kliplev bygget samtidig med præstegården, og af samme mand, altså Jacobsen, hvilket begrundes med ligheder i paneler m.m. Det skal dog nævnes, at midterkvisten på kroen først er opsat i $1852 . .^{5}$

Selv om vi her beskæftiger os med verdslige bygninger, bør det dog nævnes, at Lorentz Jacobsen også arbejdede med kirker: reparationer, nybygninger m.m., bl.a. nyt våbenhus (1755), på Kliplev Kirke 174766, reparationer m.m. på Sct. Nicolai Kirke i Åbenrå 1758, reparationer og nyt våbenhus på Hjordkær Kirke 1861-62. På sidstnævnte opsatte han endvidere et solur med ordene "Soli Deo Gloria" (Gud alene æren) og initialerne "L.I.« Den samme slags solure genfinder vi på Uge Kirke 1750 (+ombygninger) og Ensted Kirke 1771, begge med samme monogram, L.I. Dem må Jacobsen altså også have opsat. ${ }^{6}$

I 1750 'erne blev der ikke bygget meget, og faktisk skal vi op omkring 1770 , før der for alvor kommer gang i byggeriet. De næste 30 år var til gengald gode. Den blomstrende handel gjorde, at der kom penge mellem folk, og netop i denne periode finder vi mange af de bedste huse.

Dog blev der i 1758 opført et fornemt hus i Åbenrå, det palæagtige Søndergade 20, Postholdergården. Det er nok byens fineste hus overhovedet, typisk rokoko. Det er 8 fag langt, to stokværk højt, gulpudset med hvide kvaderliséner indrammende midterpartiet og husets hjørner. Noget af det mest karakteristiske er de rytmisk svungne 


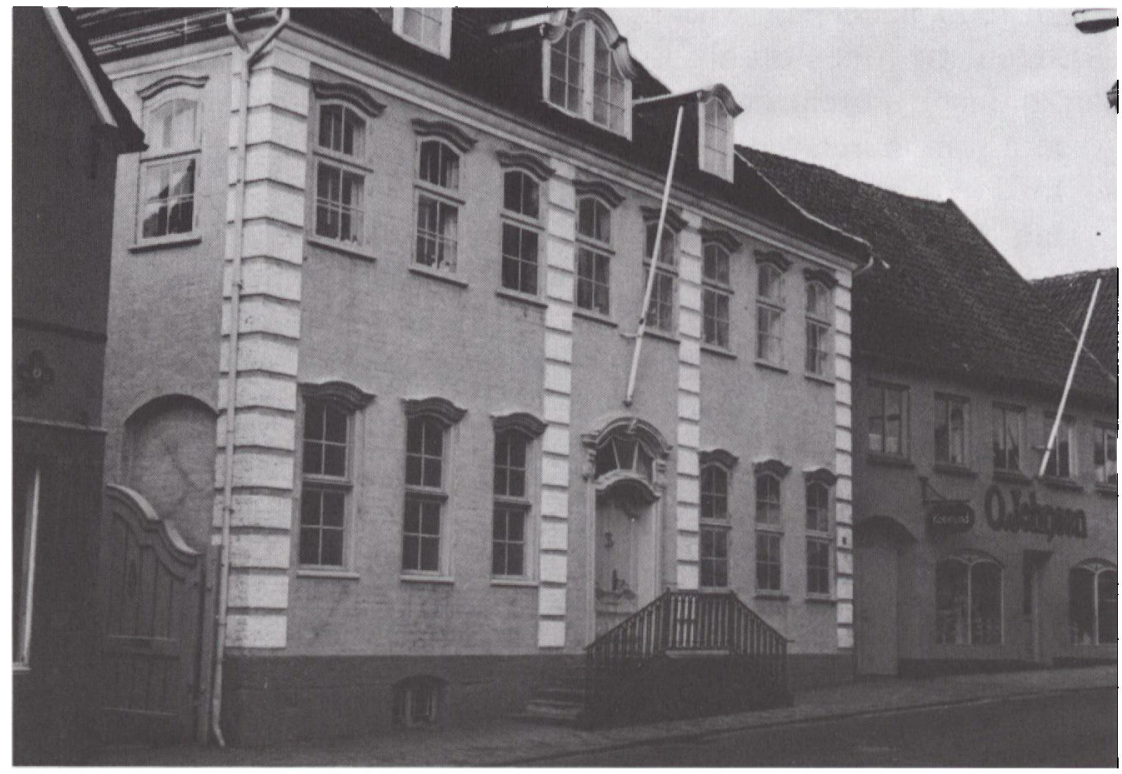

Fig. 1. Det fineste hus i Abenrå, Postholdergdirden, Sondergade 20. Sandsynligvis opfort af bygmester Lorentz Jacobsen i 1758 (alle fotos af J.Tofft, 1985-86).

vinduesbryn, der også ses ved døren og kvistene i taget. Dørpartiet er relativt enkelt. Fin rokokodør og stort overvindue med bryn båret af små svungne volutter (fig. 1). Arkitekten er ukendt; men det vil absolut ikke være urimeligt at knytte Lorentz Jacobsens navn til Postholdergården. Han må uden tvivl have været egnens førende bygmester i tiden, og ham må bygherren, postmester Herman Daniel Linde, have taget til byggeriet. ${ }^{7}$ Dette underbygges også af, at vi i andre af hans byggerier finder de samme træk, f.eks. i dørpartiet på den lidt senere opførte Skovbølgård (se fig. 5-6).

Det eneste andet hus i Åbenrå, der umiddelbart ligner Postholdergården, er det dejlige langhus Slotsgade 14, opført 1767 for Nicolai Heissel (fig. 2). Huset er 9 fag langt $i$ to stokværk med port. Her genfinder vi de svungne vinduesbryn som på ovennævnte hus. Pilasterportalen omkring hoveddøren bærer over sig hustavlen indrammet af svungne profiler. Netop den svungne linie er typisk rokoko, og på denne egn vel også typisk bygmester Jacobsen.

Fra ca. 1780 er pilasterportalerne i byen retvinklede i deres afslutning over døren i deres indramning af hustavlen, se f.eks. Nybro 14 fra 1781 (fig. 4) og Fiskergade 8 fra 1779, et nyklassicistisk træk. 


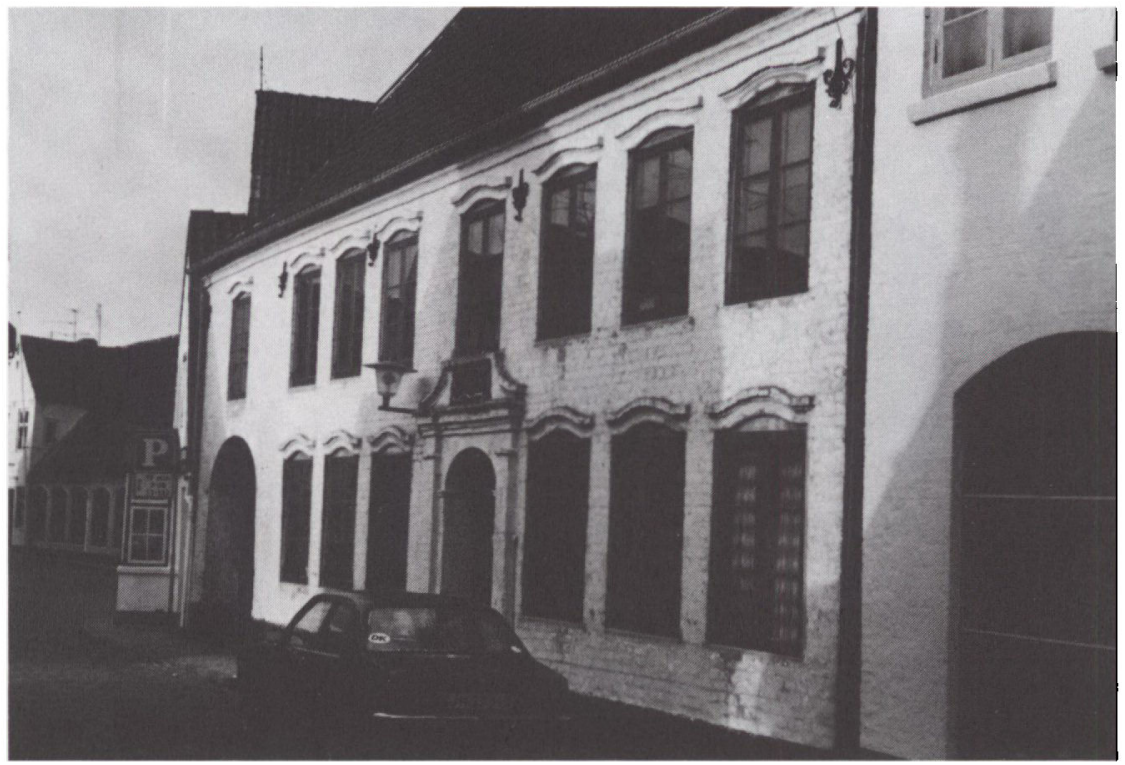

Fig. 2. Slotsgade 14, Abenra. Opfort 1767, sikkert også af Lorentz Jacobsen.

Et andet typisk hus fra Jacobsen-tiden og -stilen, er Nymøllevej 28 lidt uden for Åbenrå. Et ganske pænt hus, 7 fag langt i et stokværk med en to-fags midterkvist. Det er opført i 1766, men står nu desværre $i$ en noget ombygget stil med moderne vinduer og døre.

Der er nok ingen tvivl om, at omkring 1760-70 var gavlhusenes tid forbi i Åbenrå, når der var tale om nybyggerier. Tiden sagde langhuse, og Jacobsen byggede også sådanne. Men når grunden var ældre (lang og smal), og kun gav mulighed for en gavl, gav resultatet sig selv. Af sådanne gavlhuse fra tiden bør fremhæves Slotsgade 29 i Åbenrå fra 1770 (fig. 3), hvor især dørpartiet henleder tanken på bygmester Jacobsen.

Hvad vi dog med sikkerhed ved, er, at han i henholdsvis 1763-65 og 1771 opførte de to små herregårde på Sundeved, Skovbølgård og Ballegård.

I 1735 havde justitsråd Christopher Trogillus Koch (1703-75) overtaget Skovbølgård i Felsted Sogn. Gården lå på et gammelt, vistnok middelalderligt, voldsted, og her opforte Lorentz Jacobsen den nye hovedbygning, som stod færdig i 1765 (fig. 5-6).

Det er et ret enkelt, men smukt og velproportioneret hus, der i sit 


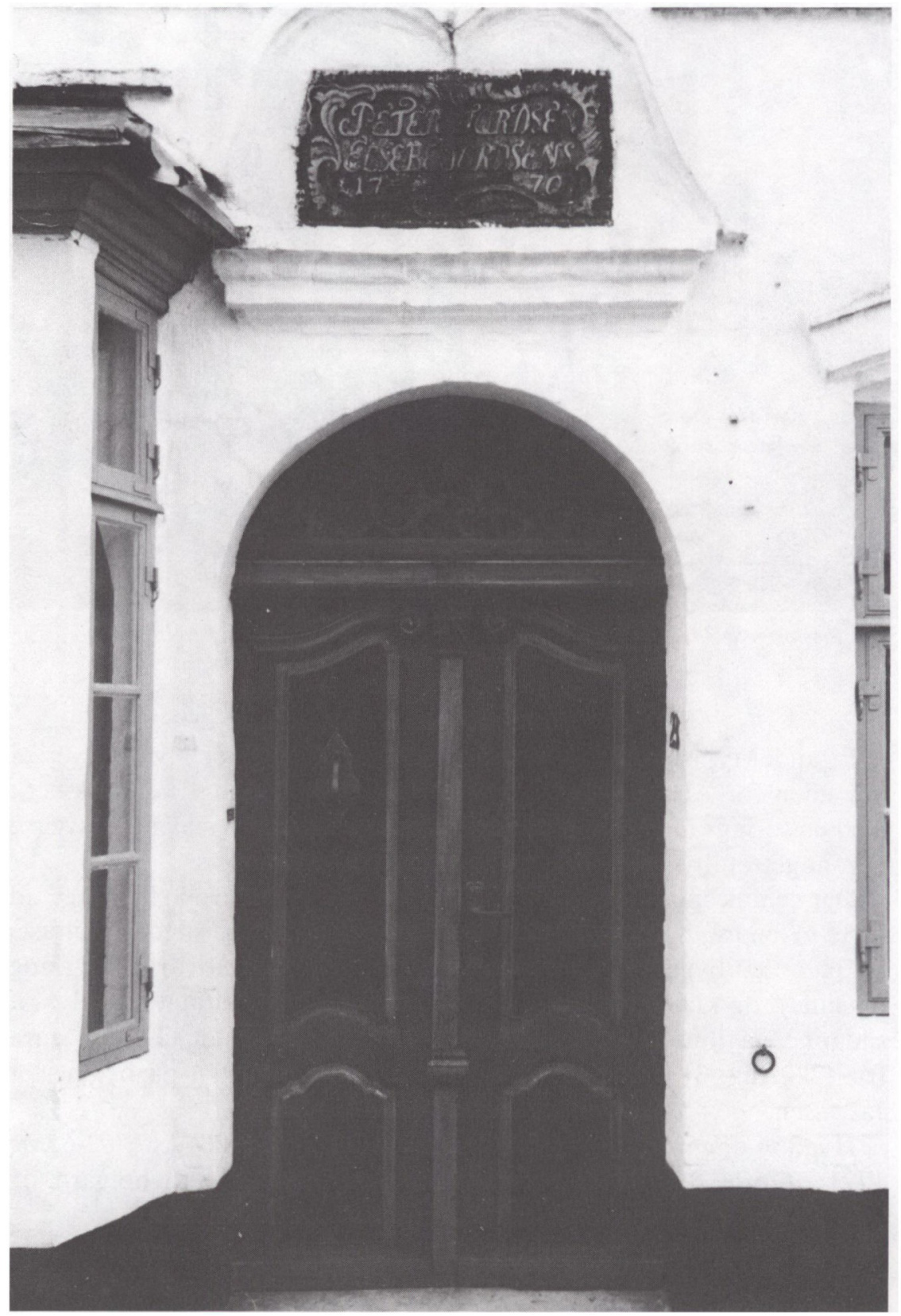

Fig. 3-4. Forskellen mellem indgangspartier $i$ rokoko- og Louis Seize-stil. Til venstre Slotsgade 29, 1770 (rokoko) og til hojre Nybro 14, 1781 (Louis Seize), begge Abenra. Bemark den retvinklede portal til hojre. 


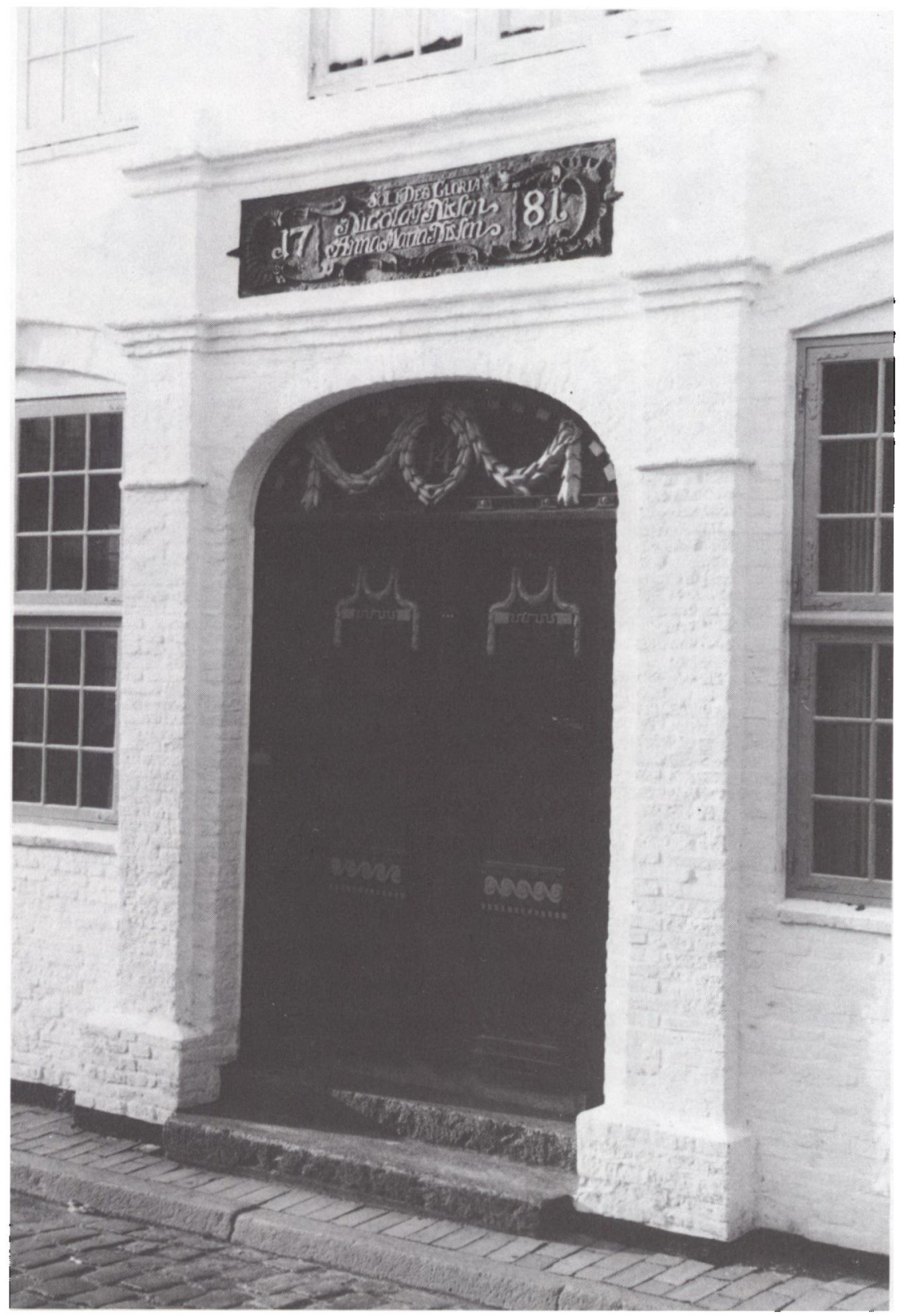




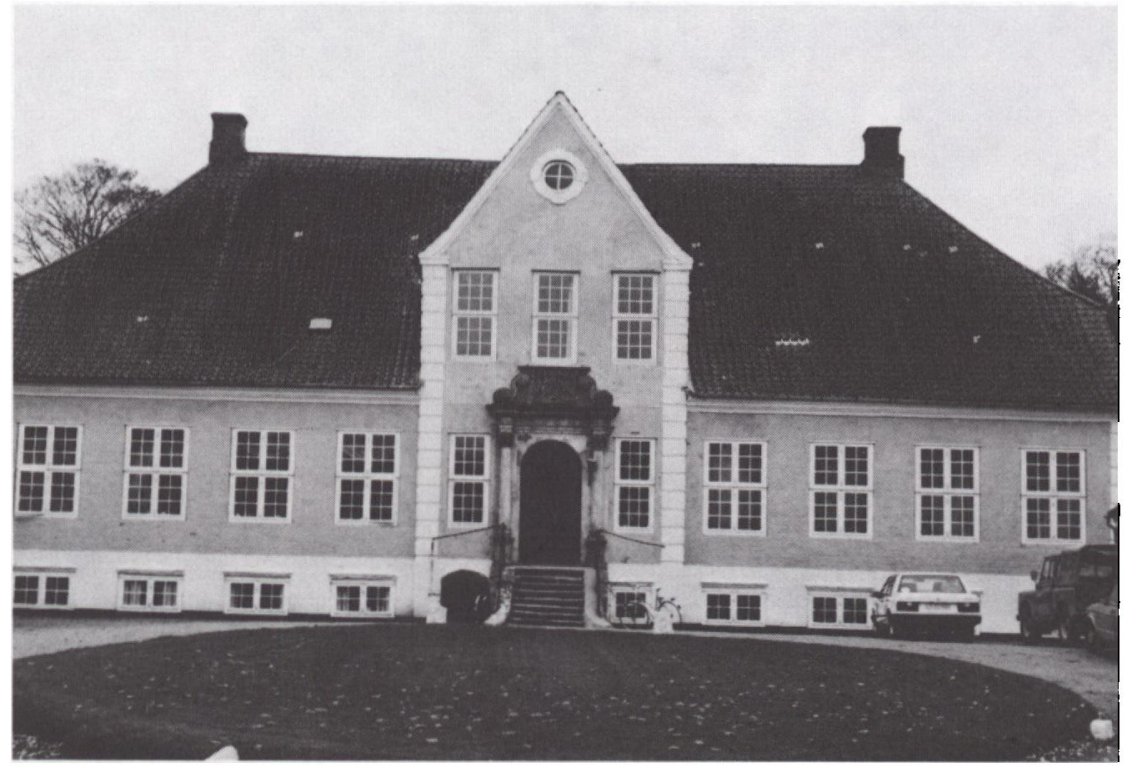

Fig. 5. Hovedbygningen pd Skovbølgård, opfort 1763-65 af bygmester Lorentz Jacobsen.

anlæg knytter sig symmetrisk til det store voldsted og til tilkørslen over graven. Hovedbygningen og gårdrummet flankeres af to lavere ladebygninger (opført 1760), der ligesom hovedbygningens gårdfacade står pudset okkergule. Begge har dog senere fået tilføjet kviste. Hovedbygningen er $\mathrm{i}$ et stokværk på høj kælder, 11 fag langt med to-fags midterkvist over døren. Gavlene og havesiden står i ren gulstensmur.

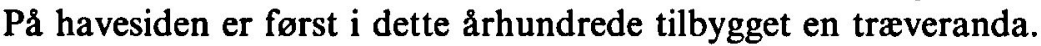

Som tidligere nævnt leder indgangspartiet tanken hen på Kliplev Præstegård og Postholdergården i Åbenrå. Faktisk er portalen på Skovbølgård en fornemmere udgave af Postholdergårdens. På samme måde er midterpartiet indrammet af hvide kvaderliséner, ligesom også husets hjørner prydes af samme. Døren flankeres af korinthiske halvsøjler, støttende en arkitrav, hvorover Kochs våben indrammes af volutter. Selve døren er identisk med Postholdergårdens.

Indendørs gennemskæres huset af en stor diele med en bred trappe. Til højre ligger salen, der kun er magert stukkeret. I en mindre stue er væggene beklædt med gamle tapeter, skildrende diverse jagtscener, der nok kunne forekomme at være en del ældre end bygningen selv. Tapeterne er dog i meget dårlig stand, og lignende skulle angiveligt tidligere også have beklædt salens vægge. ${ }^{8}$ 


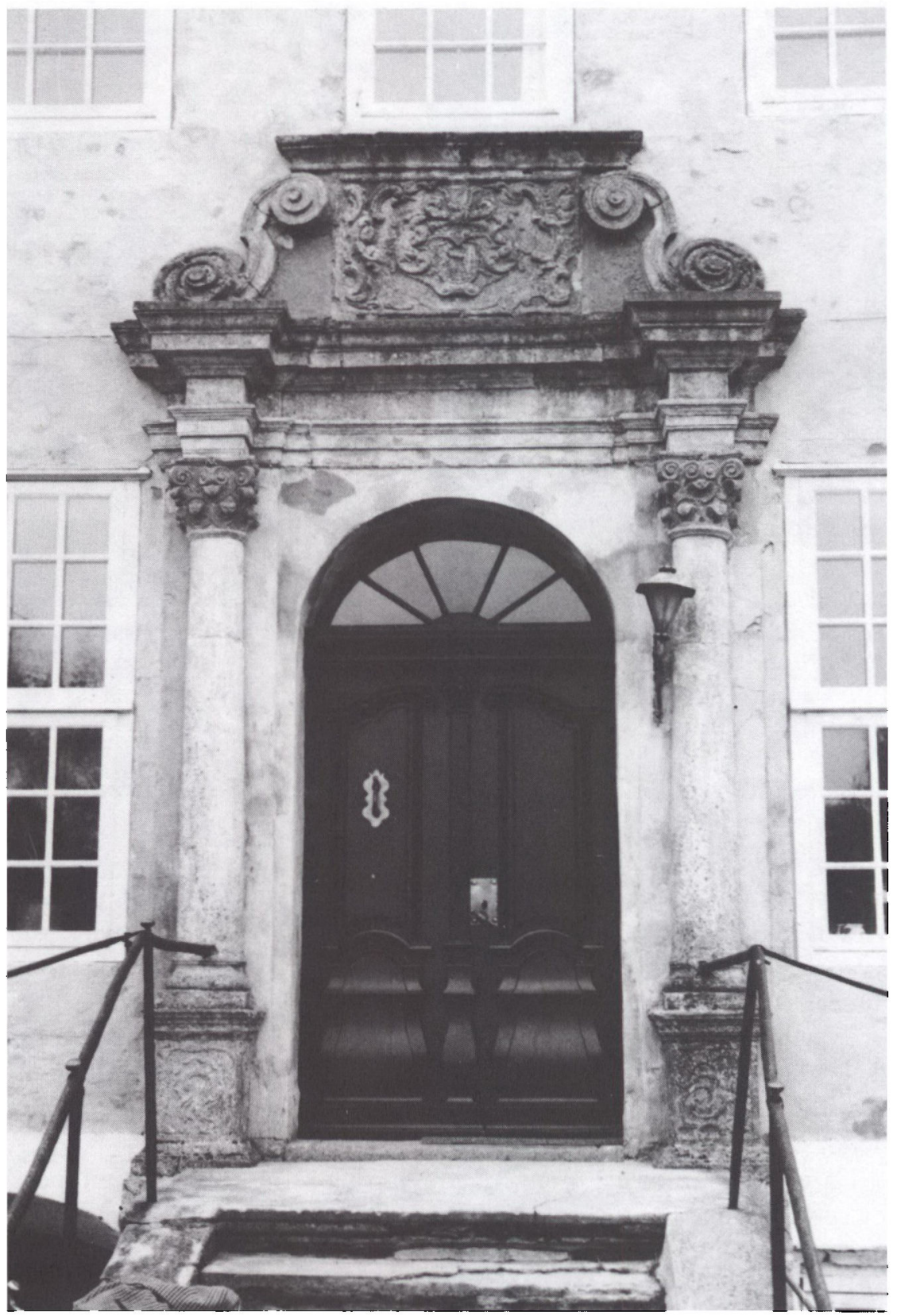

Fig. 6. Portalen, Skovbolgård - en fornemmere udgave af Postholdergdrden fig. 1. 


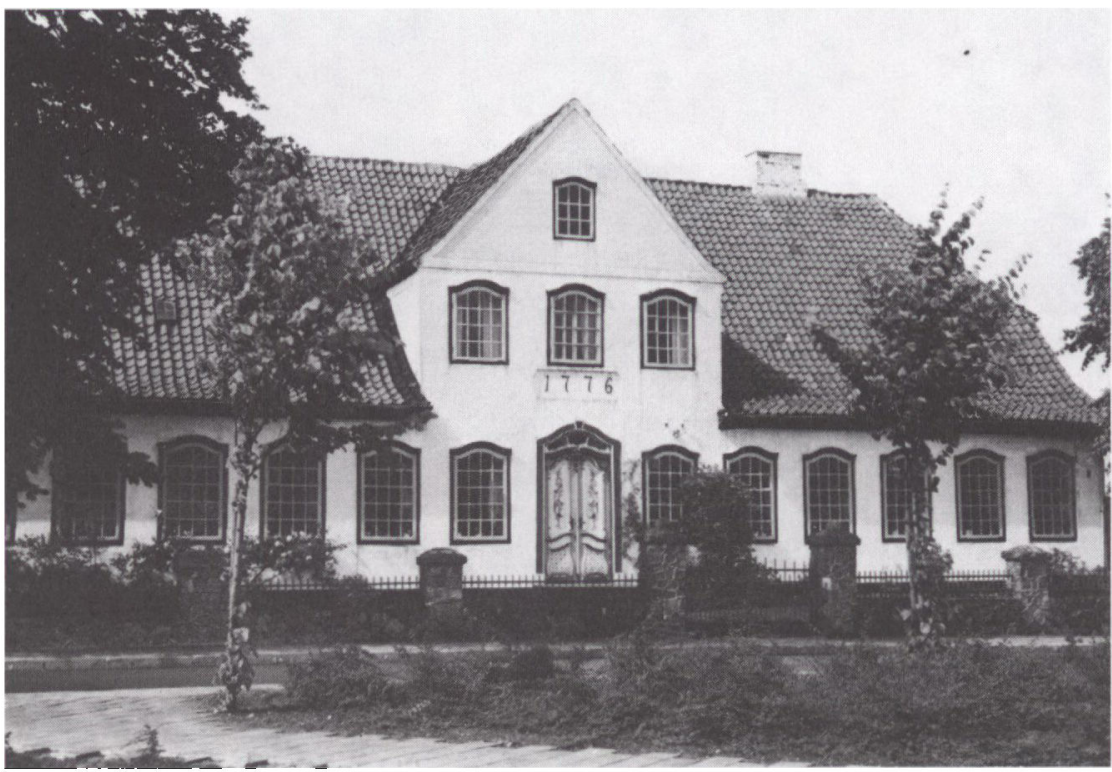

Fig. 7. Den smukke tidligere slotsprastegård i Augustenborg. Bemark de rytmisk svungne vinduesrakker. Opfort 1776, utvivlsomt af Lorentz Jacobsen.

Ballegård ved Ballebro nær Blans er en anden lille herregård på egnen. Den er med sikkerhed opført af Lorentz Jacobsen, og stod færdig i $1771 .^{9}$ Her har bygmesteren dog skiftet stil. Den to stokværk høje og 11 fag lange hvidkalkede bygning, er nøgtern i sit udtryk. Den virker klassicistisk enkel i facaden, da den er renset for pynt som kvaderliséner og portaler. Måske ligger det i krav fra bygherrens, kancelliråd Henning Paulsens side. Bygningen er dog meget sikket proportioneret, og valmtaget slutter huset pænt foroven. Indendørs er dielen næsten identisk med dielen på Skovbølgård, som Henning Paulsen iøvrigt overtog i 1776 . Interiørerne er ganske gode med rocailledekorationer i stuk, dørstykker m.m.

I året 1770 opførte Lorentz Jacobsen den ret store gård Tummelsbjerg ved Rinkenæs. På Landsarkivet i Åbenrå haves Jacobsens originaltegning sammen med byggekontrakten, utvivlsom de eneste bevarede originale akter fra bygmesterens hånd. ${ }^{10}$ Bygherren var Jørgen Thaysen. Gården er dog nu delvis ombygget.

Vi er nu ved at være fremme ved den tid, da Jacobsen begyndte sin Augustenborgtid. Måske var det gennem ejerne af Skovbølgård og 
Ballegård, der om ikke var adelige, så dog tilhørte de højere lag, at Jacobsen fik kontakt med hertug Frederik Christian 1. af Augustenborg (egentlig: hertug af Slesvig-Holsten-Sønderborg-Augustenborg). I hvert fald finder vi ham beskæftiget med slotsbyggeriet i 1770'erne."1 Selve slottet omtales i næste afsnit, men to bemærkelsesværdige huse, der bærer hans rokoko-præg, bør omtales.

Augustenborgs fineste hus er den tidligere slotspræstegård, Palævej 7 (fig. 7). Det er noget nær det smukkeste provinsrokokohus, man kan tænke sig. Det blev opført i 1776 til slotspræsten Chr. Jessen, men fungerede ikke efter hans tid som præstebolig. Det 13 fag lange kvistgavlhus udmærker sig ved sine gode former, og ved sine vinduer og døre. Vi genfinder her de smukt rytmiske svungne overrammer over de småsprossede vinduer, som harmonisk og selvfølgeligt fortsætter op i kvisten. Den i hvide og brune nuancer malede hoveddør, er måske hele rokoko-epokens fineste på egnen. Også overvinduet er smukt og behersket udskåret. Dørkarmen er af samme riflede type som på slottet, og som også ses på andre af byens huse.

Storegade 23 i Augustenborg er et betydeligt mindre hus end slotspræstegården, men er lidt af samme type. Særlig er vinduerne af samme slags med små sprosser og svungne overrammer. Udskæringerne på såvel dør som overvindue, er meget fint og sirligt udskåret som rocaillevariationer over drueranker, en plante, der også beklæder husets facade. Det er antagelig opført ca. 1775 (fig. 8). ${ }^{12}$

Begge disse huse har bygmester Jacobsens stilpræg og blev opført, mens han virkede ved slotsbyggeriet, så de kan næsten ikke være opført af andre end ham.

Før vi forlader den egentlige rokoko-epoke, vil vi dog lige se på et par bygninger, der fortjener at blive fremhævet, men som Jacobsen ikke kan have opført, da de er bygget efter 1779, hvor han døde.

Det drejer sig om Benniksgård ved Rinkenæs, opført 1782. I sin stil og sine proportioner, peger bygningen mere tilbage end frem $\mathrm{i}$ tiden. Som nævnt kan gården ikke være bygget af Jacobsen, og bygmester Chr. Aug. Bohlsmann kan det heller ikke have været, da det slet ikke er hans stil. Det har nok været en helt tredie, som måske også 5 år senere, 1787, har stået for Felsted præstegård, der har nogle af de samme stiltræk (fig. 9). Denne præstegård er et overmåde charmerende anlæg, stråtækt, 3-længet og med en meget fin portal. For både præstegården og Benniksgård gælder det, at de smalle frontispicer ikke tyder på en af de mere fremtrædende bygmestre. En sådan ville uden tvivl have anvendt andre proportioner, især bredere frontispice, højere sok- 


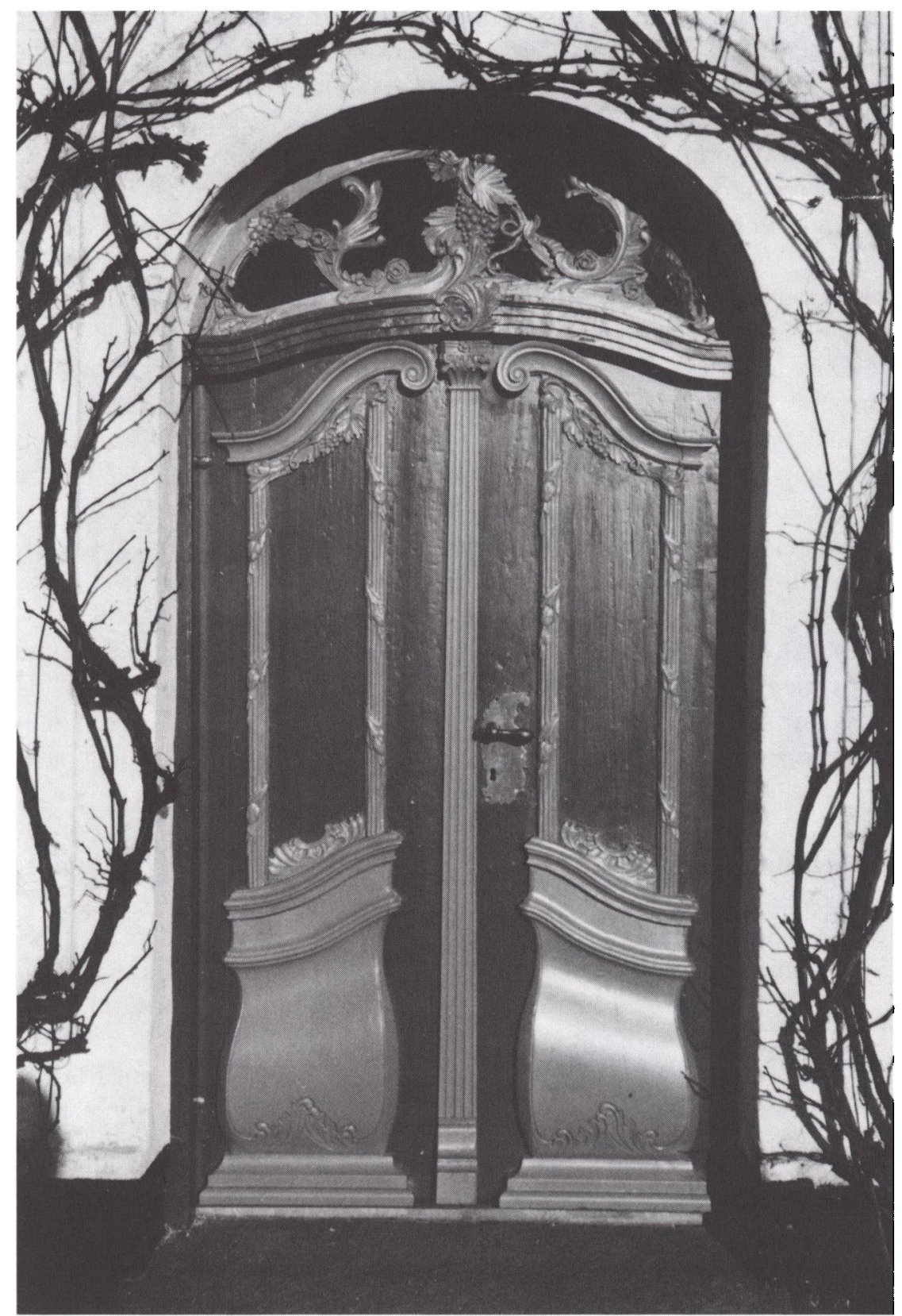

Fig. 8. Meget fint udskåret rokokodør, ca. 1775. Storegade 23, Augustenborg. 


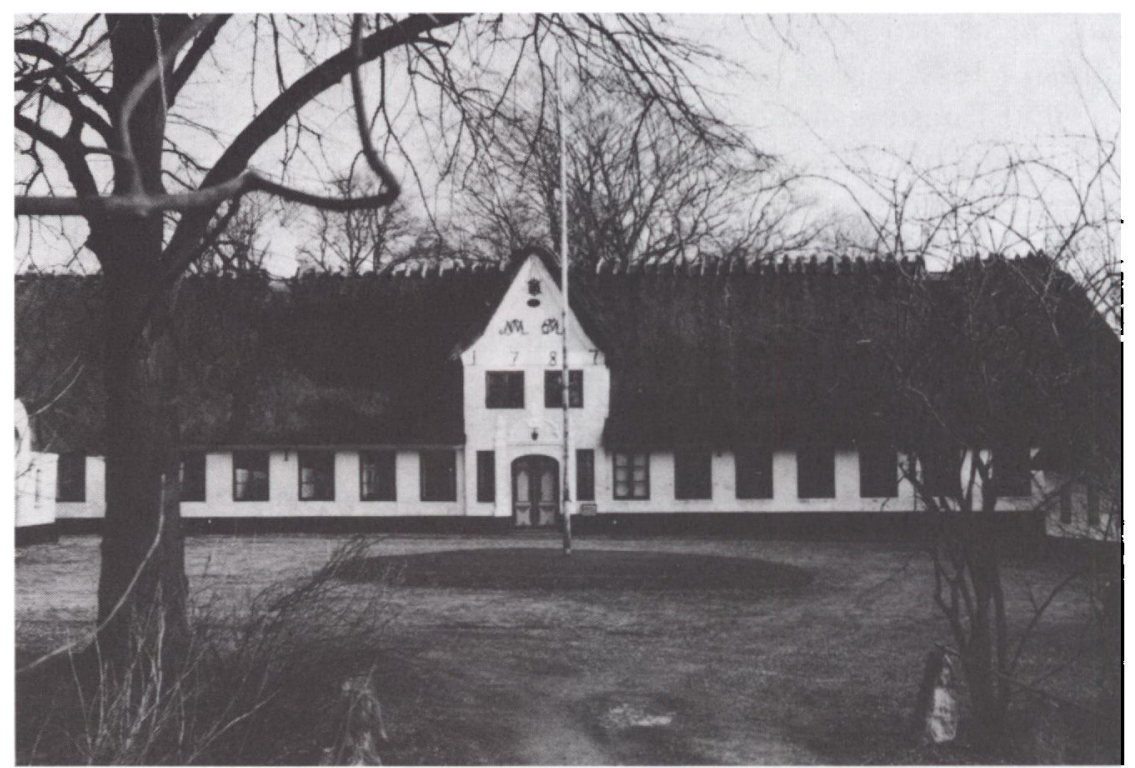

Fig. 9. Den idylliske Felsted Prastegård. Opfort i 1787 af ukendt bygmester $i$ en slags forsinket rokokostil.

kel og mindre størrelsesforskel mellem facadens højde og tagets højde, dvs. en mindre landlig stil.

Slotsbyggeri

Periodens slotsbyggeri på egnen begynder med den delvise genopbygning af Gråsten Slot, der var nedbrændt i 1757. Selv om den augustenborgske hertugfamilie mest opholdt sig på Augustenborg, var de fra 1725 også ejere af Gråsten, idet den tidligere ejer, Carl Ahlefeldt, dette år gik fallit. Ved auktionen over boet købte hertug Christian August 1. og hustru Frederikke Louise (født Danneskiold-Samsøe) Gråsten med flere storgårde.

Efter optegnelser og billedgengivelser ved vi, at det var et vældigt imponerende barokanlæg, der gik til i flammerne. ${ }^{13}$ Hovedfløjen var 3 stokværk høj, og det fremhævede midterparti endda hele 5 stokværk.

Af hele det fornemme slot overlevede kun en del af den nordre fløj med kirken branden. I 1758-59 blev slottet ikke genopbygget i sin tidligere stil, men i en reduceret udgave. Den sydlige fløj blev genopført, den nordlige restaureret, men de to fløje blev kun knyttet sammen af en lav forbindelsesfløj kaldet "Langegang«. De to fløje står den dag i 
dag, mens den vestre forbindelsesfløj har fået det 3-etages tårnhus tilføjet i 1842.

Til at forestå genopbygningen havde man engageret arkitekten Johann Gottfried Rosenberg (1709-76), der på den tid var en af landets førende arkitekter. Han stammede fra Plön, hvor han havde en stilling som bygningsinspektør ved det lille fyrstehof. Fra 1760 var han tillige $\mathrm{kgl}$. landbygmester $\mathrm{i}$ hertugdømmerne. Ved siden af arbejdede han en del i kongeriget, og havde bl.a. arbejdet en del sammen med arkitekten Nicolai Eigtved i København. Her forestod han i hovedsagen selv opførelsen af de 3 fornemme palæer i Bredgade, nemlig Dehns, Bernstorffs og Berckentins palæer (Odd-Fellowpalæet). ${ }^{14}$

Et karakteristisk facadetræk på disse og andre bygninger i Frederiksstaden, er de såkaldte »øreliséner«, murfremhævelser mellem vinduerne med et lille knæk i hjørnet. Disse liséner anvendte Rosenberg også i facaden på Gråsten Slot ved renoveringen, og kort efter, i 1761, blev de også anvendt, da han opførte herregården Vindeby ved Eckernförde. Senere anvendtes øreliséner mange steder på egnen, men det var Rosenberg, der introducerede denne form for facadeudsmykning på det nye Gråsten Slot. ${ }^{15}$

I 1762 var hertug Frederik Christian 1. for alvor kommet til penge gennem giftermålet med prinsesse Charlotte Amalie Vilhelmine af Plön, så nu kunne et længe planlagt nybyggeri ved Augustenborg tage sin begyndelse.

Det gamle Augustenborg Slot, der var opført ca. 1660-63 af hertug Ernst Günther 1., vides der ikke meget om; men på en billedgengivelse fra Resens Atlas ca. 1670, ses at det drejer sig om en 4-længet renæssancegård $\mathrm{i}$ bindingsværk. ${ }^{16}$

Det nye Augustenborg med staldgård blev bygget i årene 1764-76, men faktisk begynder bygningshistorien allerede med den i 1733 opførte "Marstald«, der blev bygget foran slottet på den gamle ladegårds plads. Denne var efter en brand samme år flyttet et stykke mod nord. Af denne nye ladegård er der nu kun en stor lade tilbage. Men marstalden, der var beregnet til de finere køre- og rideheste, lå altså i 30 år alene på den gamle ladegårds plads, og først i 1760'erne, hvor godserne udvidedes kraftigt til ialt ca. 30.000 tdr. land, var der basis for et nyt stort byggeri.

Marstaldens placering allerede i 1733 sandsynliggør derfor, at man allerede da havde planer om et stort barokanlæg, hvilket måske kan forklare, at det samlede anlæg, da det stod færdigt i 1776, var bagefter rent stilmæssigt. Hvem der har bygget marstalden, vides ikke; men 
muligvis kan det dreje sig om Otto Johan Müller (1692-1762), der virkede som kgl. landbygmester før Rosenberg.

Augustenborg Slot minder i mangt og meget om Gråsten. Først i dispositionen med et 3-fløjet anlæg med hovedfløjen beliggende nordsyd. Endvidere planen med slotskirken i nordre fløj, og springet fra tre til to stokværk i sidefløjene. Endelig er også Augustenborgs facader markeret med øreliséner. Dette kunne tyde på, at Rosenberg også var ophavsmand til Augustenborg. Under alle omstændigheder er inspirationen herfra. Fordi den senere hertug Frederik Christian 2. i sit testamente bestemte, at alle arkivalier skulle brændes efter hans død, har der nemlig hersket uvished om, hvem der har været arkitekt for det nye slot, da alle tegninger, regnskaber m.v. således er brændt. Både Jørgen Paulsen og Flemming Jerk finder det sandsynliggjort, men ikke uomtvisteligt, at arkitekten var Rosenberg. ${ }^{17}$ Weilbachs Kunstnerleksikon nævner slet ikke Augustenborg under omtalen af Rosenberg, mens Peter Hirschfeld uden forbehold omtaler Augustenborg som Rosenbergs "seneste og vel største byggeri火 ${ }^{18} \mathrm{Vi}$ vil derfor med en anelse forbehold udnævne Rosenberg til slottets hovedarkitekt, se senere.

$\mathrm{Da}$ Rosenberg nu skulle i gang med det nye slot, var han ikke ganske frit stillet, men havde den eksisterende marstald som udgangspunkt. Der opførtes derfor i 1764 direkte nord for denne en nøjagtig pendant dertil, kun bygherremonogrammerne i midterfrontonerne er ændret. Længerne er opført i gule sten $i$ et stokværk med højt valmtag i rødt tegl. De er 25 fag lange, og facaderne brydes af en midterportal med pilastre og hertugparrenes monogrammer indrammet af dobbeltsvungne volutter $\mathrm{i}$ en fronton, og af to dørpartier symmetrisk på hver side af portalen. Den nye nordre længe anvendtes til både ridehus, tjenesteboliger og kontorer. De to længer blev bundet sammen af portbygningen i samme udførelse. Den består midterst af det to etager høje tårnhus. Nederste etage udgøres af selve porten, mens der herover ses en etage med $3 \mathrm{fag}$ adskilt af øreliséner, i trekantfrontonen et ur, og øverst selve klokketårnet (fig. 10). På hver side af tårnhuset de lidt lavere sidefløje med hver 3 vinduer adskilt af vognporte. Portbygningen menes opført ca. 1765-67, da klokkerne er støbt i Eckernförde i 1767. ${ }^{19}$ Samtidig med nordre staldlænge opførtes i noget nær samme stil, umiddelbart nord for denne, en vaskeribygning, og $\mathrm{i}$ årene herefter en køkkenbygning overfor denne igen, dvs. lige nord for det senere slot.

Hermed var første del af byggeprogrammet tilendebragt, og man kunne tage fat på hovedopgaven, selve slottet. Det gamle slot har 


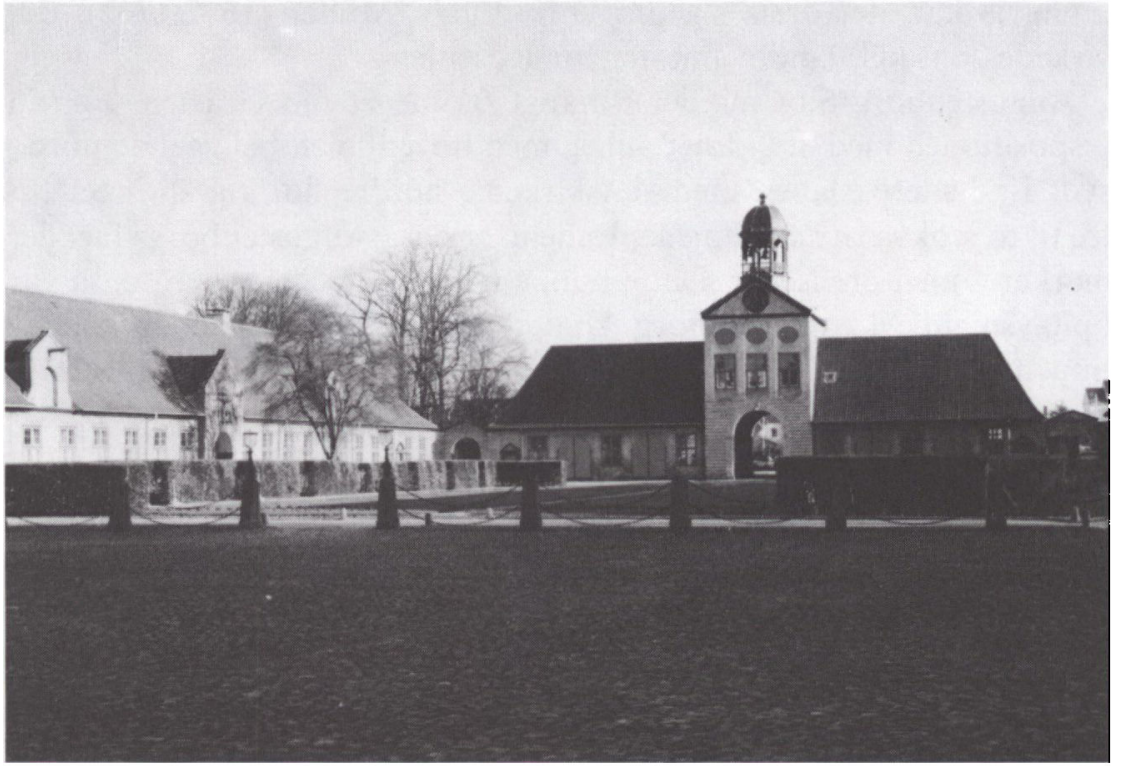

Fig. 10. Augustenborg Slot. Staldgdrden med porthuset, opfort 1764-67.

formodentligt ligget lidt sydvest for det nye, således at hertugfamilien kunne blive boende under byggeperioden. Det nye slot blev bygget over en 6-årig periode, 1770-76, i pagt med barokkens idealer anlagt aksialt og symmetrisk lige over for staldgården.

Set fra gården står man over for et meget monumentalt bygningsværk i 3 stokværk (fig. 11). Murfladerne er hvidpudsede med gulkalkede, lodrette bånd mellem vinduerne, fagopdelingen er brede øreliséner. Taget er afvalmet og beklædt med sortglasseret tegl. Det øverste stokværk er mindre end de to nederste. Den 15-fags hovedfløjs midte - og dermed hele anlæggets centrum, hvorigennem hovedaksen går - er fremhævet af en 3-fags let forhøjet midterrisalit, der øverst afsluttes af en trekantfronton med et fladt, brunmalet sandstensrelief med bygherrens monogram omgivet af trofæer og attributter. Ellers brydes hovedfløjens gårdfacade kun af 3 ret uanseelige døre, fladbuede med riflede karme, strengt symmetrisk anbragt.

De ret korte sidefløje i 5 fag, og ellers som hovedfløjen, efterfølges af lidt lavere sidepavilloner i 2 stokværk og 7 fag, og hvoraf den nordre huser slotskirken. Havefacaden med de 19 fag ligner gårdfacaden, men er endnu mindre varieret (fig. 12). Fagenes rytmik brydes kun af midterrisalittens enlige dør og balkonen lige ovenover. Farvemæssigt 


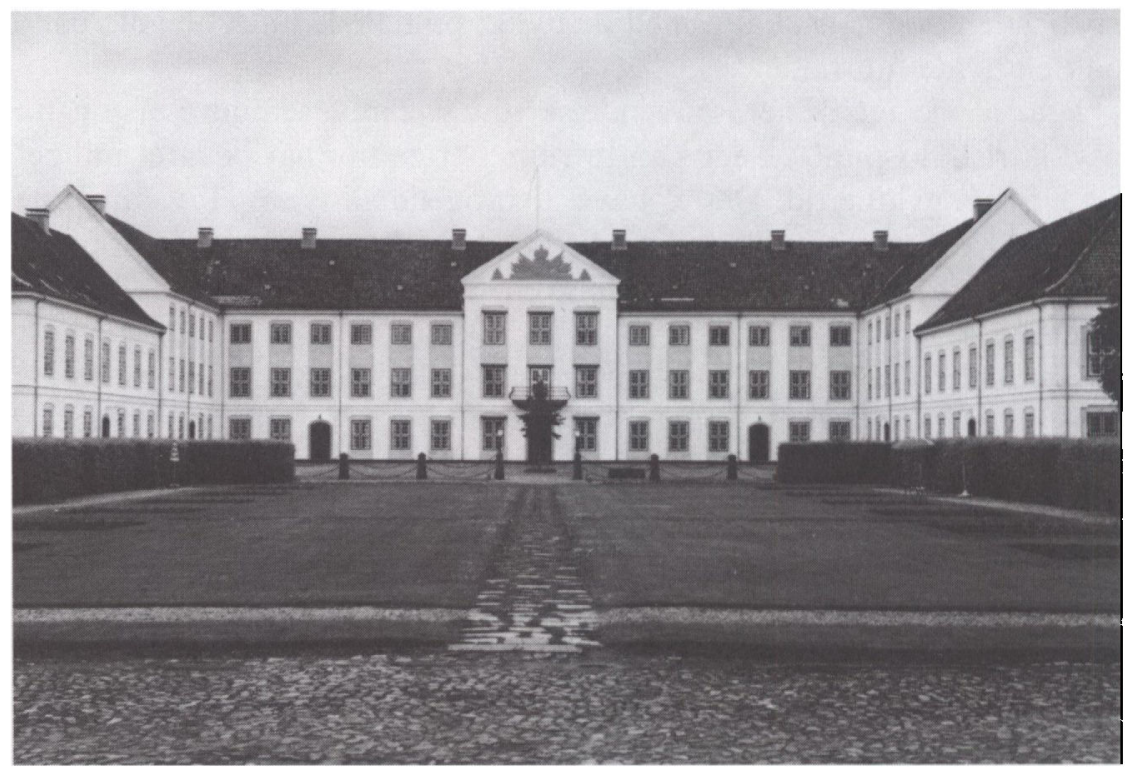

Fig. 11. Augustenborg Slot set fra gården, opfort 1770-76. Formentlig planlagt af kgl. landbygmester Johann Gottfried Rosenberg og fuldfort af bygmester Lorentz Jacobsen.

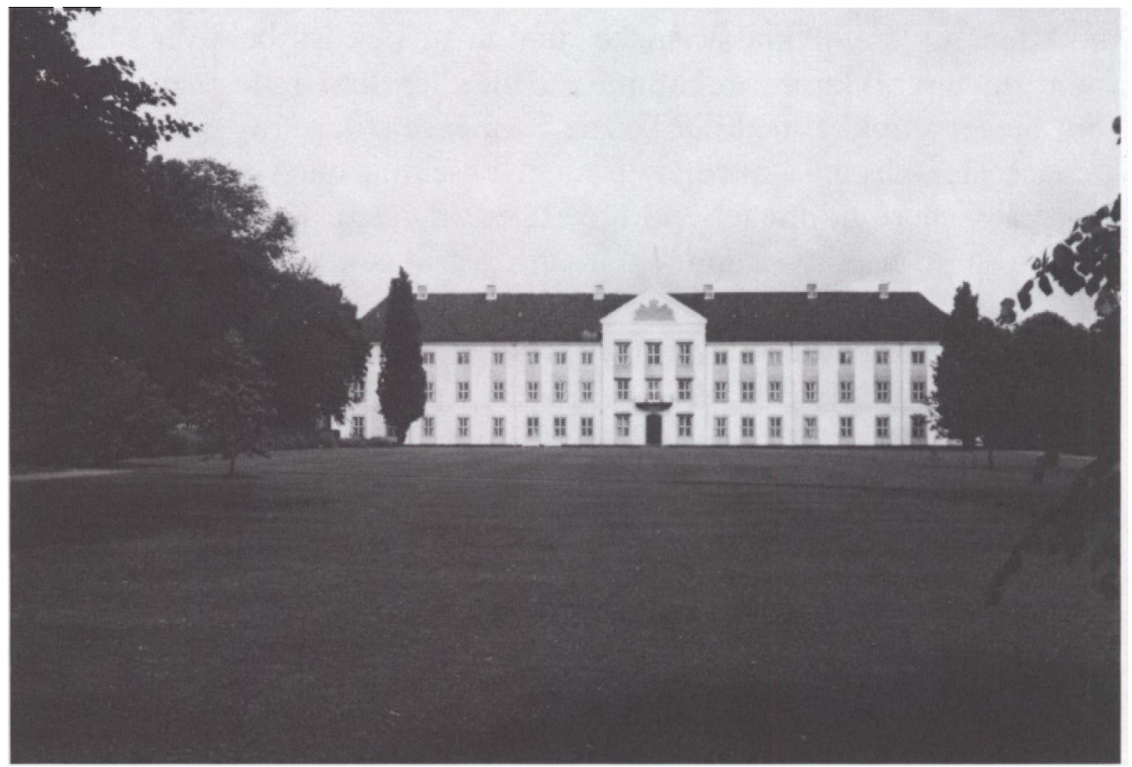

Fig. 12. Augustenborg Slot, den massive havefacade. 
er facaden dog ganske flot med de nyligt opmalede lodrette gule bånd på den hvide murflade.

Pga. af slottets senere anvendelse som lazaret, seminarium og nu psykiatrisk hospital, er der kun to rum, der endnu har bevaret miljøet fra slottets gyldne tid. Det er havesalen og slotskirken. Hovedlinierne i den indre disposition er dog stadig kendelige med de lange korridorer mod gården og værelserne mod haven. Hovedtrapperne er anbragt i sidefløjene.

Havesalen, der udgør hele anlæggets aksiale centrum, er på vægge og loft udsmykket med fine stukarbejder. De blev udført af den italienske stukkatør Michel Angelo Tadei fra Lugano. Han ankom til disse egne i 1777, hvor han udsmykkede væggene på Gelting, siden på Augustenborg og andre steder i Slesvig-Holsten. Det drejer sig om meget fine og fantasifulde stukrelieffer med fantasilandskaber og antikke scenerier, blomstervaser og rocaille-ornamenter (fig. 13-14). M. A. Tadei, der rejste tilbage til Lugano i 1786, arbejdede i en kraftig rokokostil, mens hans yngre bror, Francesco Antonio Tadei, arbejdede sig frem mod en typisk nyklassicistisk stil. Denne bror kom herop i $1782 \mathrm{og}$ blev her. Han udsmykkede i sin tid en lang række herregårde og andre bygninger i Slesvig-Holsten..$^{20}$

Selv om havesalens udsmykning må betegnes som rokoko, omend ret særpræget, er der alligevel træk (f.eks. panelerne), der peger frem mod den enklere, nyklassicistiske rumkunst. Faktisk behøver sådanne frembringelser ikke at forekomme rodede eller forvirrede, men derimod som meget smukke med det bedste fra begge stilarter.

Også slotskirken i nordfløjen er et eksempel på stilblanding, dog betydeligt mere udpræget end havesalen (fig. 15). Kirkerummets helhedsvirkning er et lyst rum med hvidt og gråt som dominerende nuancer. Gulvet er skakbræt-ternet sort-hvidt, mens enkelte ornamenter og bånd er forgyldte. Placeringen af alter, prædikestol og orgel over hinanden er særpræget, men kendes fra andre af tidens kirker. Både prædikestol og orgel (bygget 1773 af Johan Daniel Busch i Itzehoe), er rokoko ligesom en del stuk af Michel Angelo Tadei på loft og vægge. Derimod er galleriet over sideskibene med balustradeværn og underliggende arkitrav klart nyklassicistiske. Søjleordenen, der bærer galleriet, er nederst toscanske, over galleriet korinthisk. Alt $i$ alt er det således et meget smukt og afdæmpet kirkerum i overgangsstil mellem rokoko og Louis Seize, som nyklassicismens første fase kaldes. ${ }^{21}$ Fra en gammel tegning ved vi, at et kabinet på slottet har været udsmykket $i$ en lignende stil. ${ }^{22}$ 


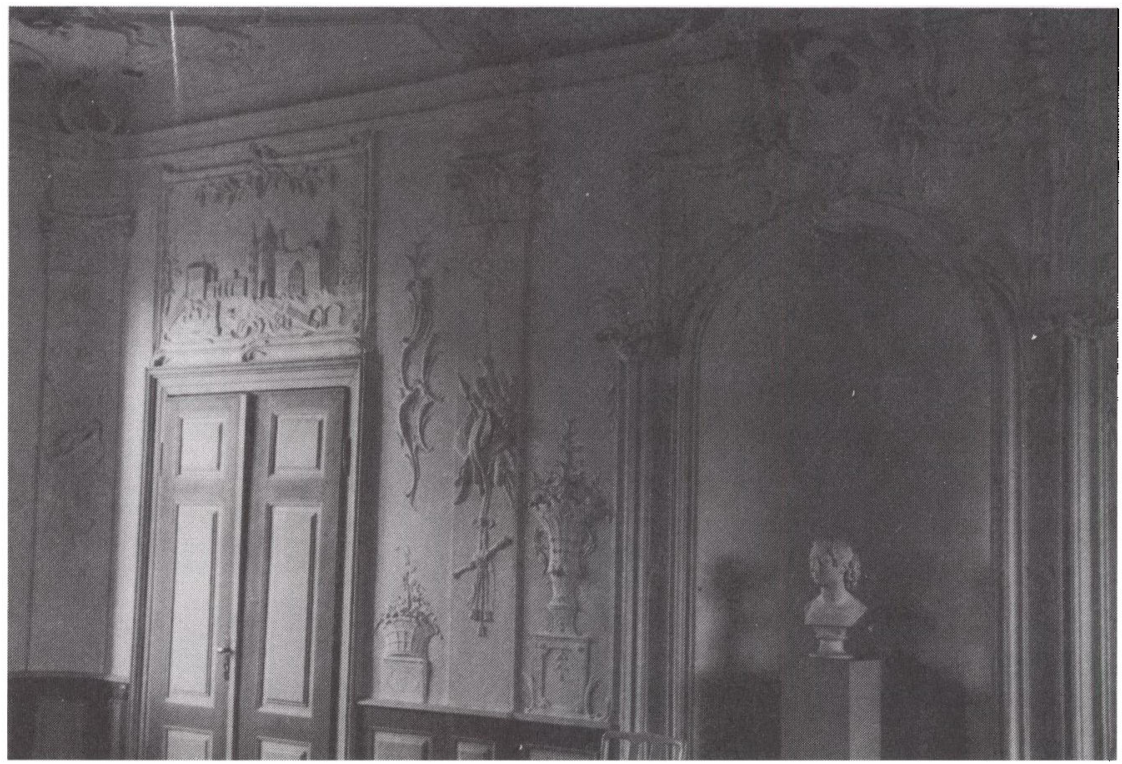

Fig. 13. Augustenborg Slot. Havesalen med stukarbejde af Michel Angelo Tadei, ca. 177778.

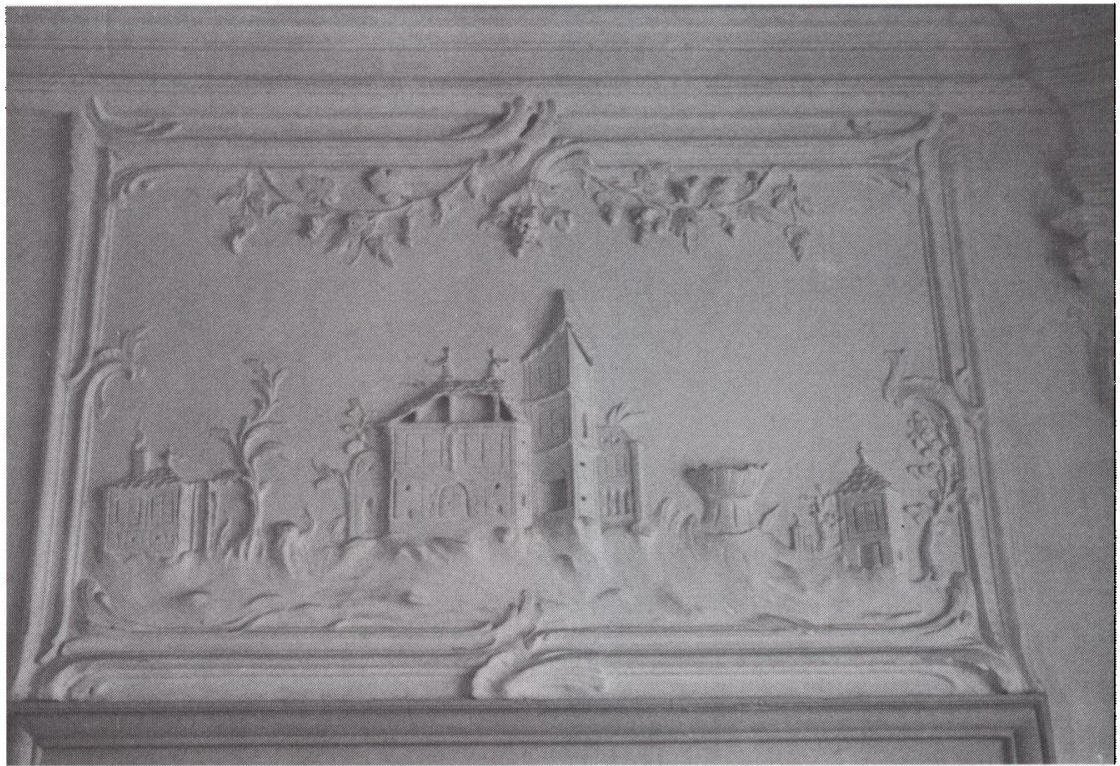

Fig. 14. Augustenborg Slot, havesalen. Dørstykke i stuk af Tadei. 


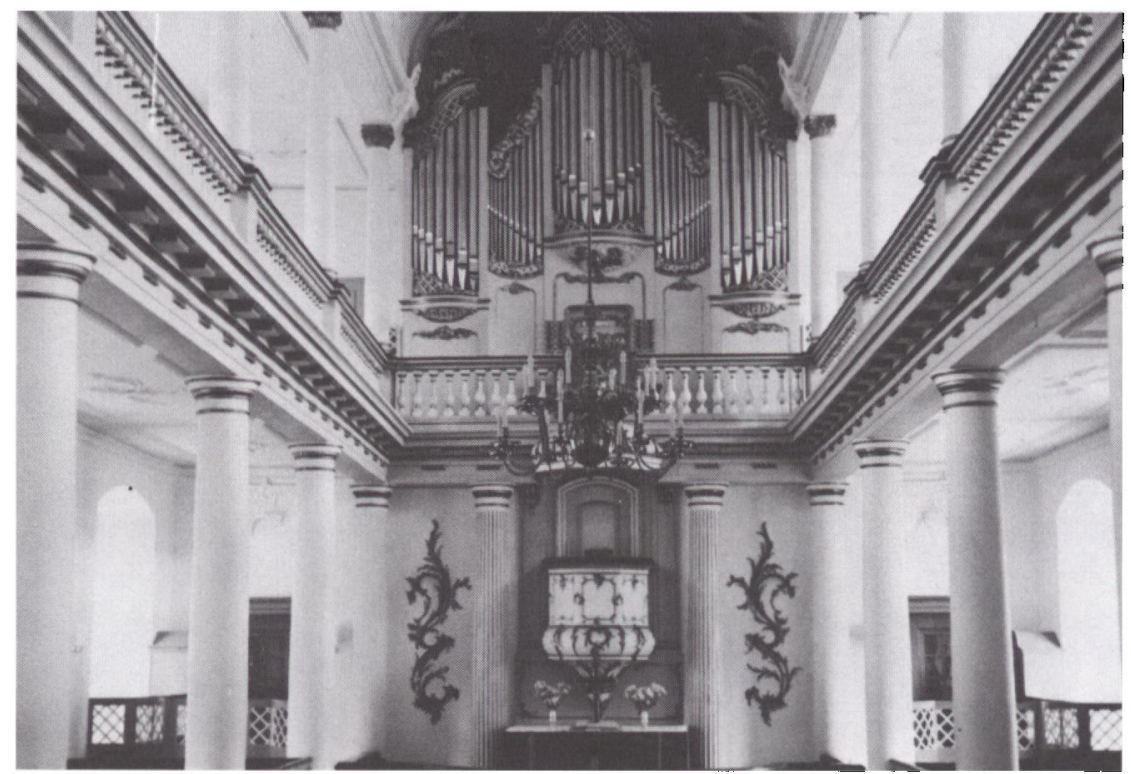

Fig. 15. Augustenborg Slot, Kirken. Interier af Lorentz Jacobsen. Stilen er en blanding af rokoko og nyklassicisme.

Vi har tidligere udnæunt Johann Gottfried Rosenberg til Augustenborgs arkitekt, selv om vi ikke har fuld sikkerhed herfor. Derimod ved vi med sikkerhed, at bygmestrene Jacobsen og Bohlsmann arbejdede med på slottet, og at førstnævnte tegnede kirken, der sikkert har været noget af det sidste, der blev lavet færdigt (jvf. Tadeis ankomst 1777). Både Jerk og Paulsen mener, at slottet, som det står med sine imponerende, men også stive og tunge facader, ikke kan have været Rosenbergs værk hele vejen igennem. ${ }^{17}$ Værket mangler noget af den elegance, der kendetegnede Rosenberg og rokokoen, den karakteristiske udsmykning og livlige facade. Midterrisalitten er for smal i forhold til den samlede facadelængde, ligesom hovedfløjens indgangspartier er lidet repræsentative, ja, nærmest overdrevent puritanske. Rosenberg ville nok også have lavet en ordentlig trappe og en høj kælder. Dette har fået Paulsen til at mene, at den ret nærige og mådeholdne hertug nok har ændret Rosenbergs (formodede) fornemmere skitser til byggeriet, og ladet de næunte lokale bygmestre lede arbejdet. ${ }^{17}$

Jeg vil derfor finde det rimeligt at antage, at Rosenberg, sikkert på et ret tidligt tidspunkt, har lavet planer for hele det aksiale slots- og staldgårdsanlæg med udgangspunkt i den gamle marstald fra 1733. 
Han har sikkert selv ledet byggeriet af staldgården med porthus, vaskeri og køkken $\mathrm{i}$ årene 1764-69. Da selve slotsbyggeriet skulle $\mathrm{i}$ gang har han, måske nødtvungent, ændret tegningerne i retning af det mere strenge og puritanske efter bygherrens ønsker. Hvad der herefter er sket, er det store spørgsmål. Måske har Rosenberg ikke kunnet komme overens med bygherren, forladt byggeriet, og ladet Jacobsen overtage arbejdet. Denne har måske derpå ændret tegningerne i samråd med bygherren, i hvert fald facadetegningerne. Nærmere kan vi nok ikke komme det. På den anden side kan Rosenberg vel stadig godt have været øverste tilsynsførende med byggeriet. Det underbygges af, at efter hans død, 4. juni 1776 i Slesvig, udnævntes Jacobsen til hertugelig bygningsinspektør. Man kan også tænke sig, at Rosenberg måske har været syg og uarbejdsdygtig $\mathrm{i}$ sine sidste år. Ved Rosenbergs død var slottet stadig ikke færdigt, og især har rumudsmykningerne manglet. Ud fra dette må konklusionen være, at det samlede slotsanlæg er et værk af Rosenberg og Jacobsen i fællesskab. Chr. Aug. Bohlsmann har uden tvivl medvirket ved hele byggeriet fra 1764 (byggede hus $i$ Augustenborg i 1764, se senere), men har nok ikke haft direkte indflydelse $i$ forhold til Jacobsen, da han var en del yngre og mindre erfaren.

Vest for slottet anlagdes en stor barokhave, der er beskrevet i C. C. L. Hirschfelds vark Theorie der Gartenkunst, bind 4, der udkom i 1782. I årene umiddelbart forinden må han derfor have besøgt den nyanlagte have. ${ }^{23} \mathrm{Han}$ omtaler haven som værende opdelt i plæner, parterrebede, blomsterhaver, frugthaver, løvbuegange samt vaser og skulpturer. Et sted på en lille høj omgivet af vand med en lille bro over, var der bygget et rundtempel af træ båret af 8 joniske søjler. Endvidere nævnes de to øst-vest-gående lindealléer, endende ved fjorden, hvor dennes kyst noget vest for slottet drejer nordpå. Den sydlige allé med gamle træer, den nordlige - i det nye slots symmetriakse med unge træer. Alt dette ses af den i 1796 opmålte plan over slot og omgivelser. Det gamle slot har sikkert ligget ud for den gamle allé. ${ }^{24}$ Hovedaksen gik så fra øst mod vest gennem Slotsallé, staldgård, slot, have og ad alléen ud til fjorden.

Augustenborg Slot er et sent, men gennemkomponeret og strengt symmetrisk barokanlæg, hvilket utvivlsomt har sin rod i en planlægning, længe før slottet blev opført. Det kan her en passant nævnes, at Rosenbergs søn, arkitekten Georg Erdmann Rosenberg (1739-88), samtidigt opførte Hagenskov ved Assens (tidl. kaldet Frederiksgave) i en helt anden og mere moderne stil med hovedbygningen uden direkte 


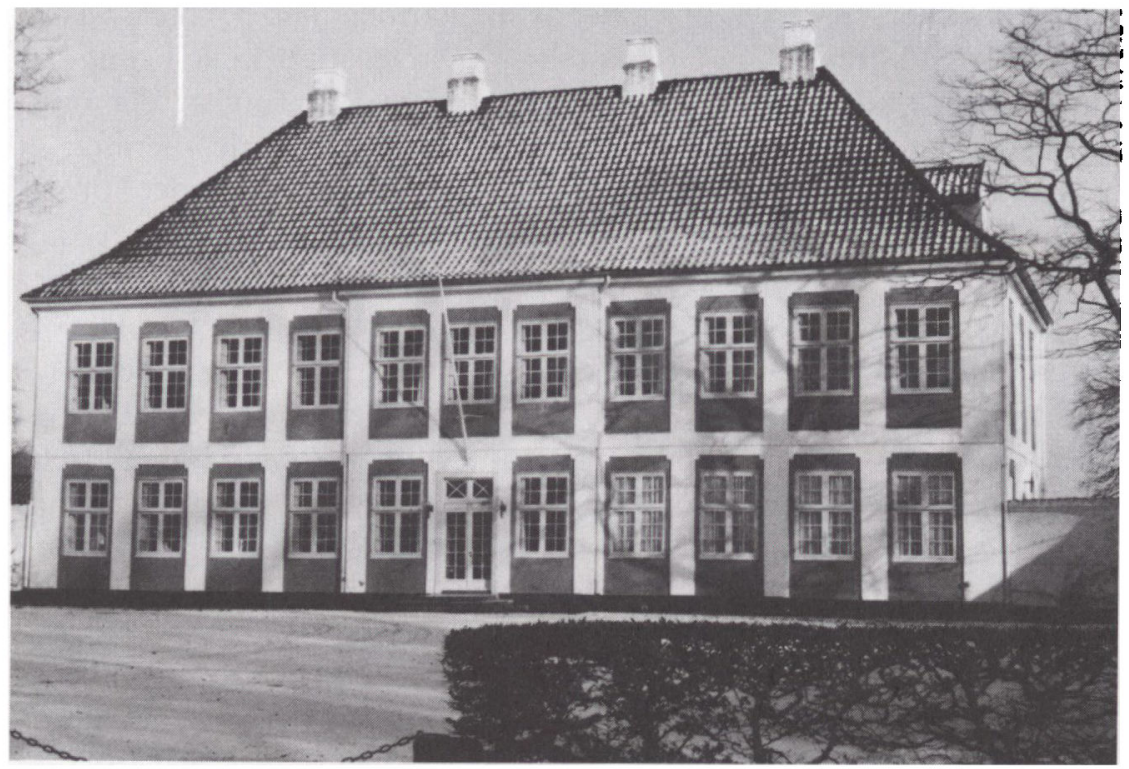

Fig. 16. Sandbjerg, opfort 1787-88 af bygmester Chr. Aug. Bohlsmann. Bemark de hvide liséner med små knak, de såkaldte moreliséner".

forbindelse med staldene, dvs. en klassicistisk løsning. Da Augustenborg Slot endvidere er fuldstændigt velbevaret i det ydre, er det mærkeligt, at dette, et af landets største barokanlæg, hidtil har været så overset i traditionel dansk arkitekturhistorie.

\section{Sandbjerg}

Selv om Sandbjerg lokalt bliver betegnet slot, er det i forhold til Gråsten og Augustenborg kun en lille herregård og bliver derfor omtalt særskilt.

Med denne idyllisk beliggende herregård ved Alssund, er vi for alvor kommet frem til bygmester Chr. Aug. Bohlsmann (1740-94), der især efter Lorentz Jacobsens død i 1779, kom til at spille en betydelig rolle for egnens byggeri.

Han var født i Gråsten ca. 1740 (måske lidt før) som søn af tømrermester Peter Bohlsmann, og både far og søn har sikkert medvirket ved genopbygningen af Gråsten Slot i 1758-59.25 Senere, i 1764, flyttede han til Augustenborg, hvor han var aktiv i de næste mange år. ${ }^{26}$

I 1787-88 blev Sandbjergs smukke hovedbygning tegnet og opført af Bohlsmann som hovedsæde for det lille grevskab Reventlow (fig. 
16). Bygherren var lensgreve Conrad Georg Reventlow (1749-1815), bror til de kendte landboreformatorer. ${ }^{27}$

Bygningen er holdt $i$ en smuk og enkel stil. De 11 fag $i$ to stokværk med meget store vinduer, giver huset en let og lys fremtræden. Over de gulkalkede vinduesfelter, opdelt af de bohlsmannske bygningers kendetegn, de hvide øreliséner, lægger valmtaget med sortglasseret tegl sig harmonisk og rigtigt. Indendørs bemærkes en god rumdisposition og stukkaturer. Sandbjerg føjer sig ikke på barokvis direkte aksialt til avlsgården umiddelbart nord herfor, men gør sig fri af denne ved sin selvstændige og værdige fremtræden.

På gårdspladsens nordlige side, $i$ en ret vinkel til hovedbygningen, ligger den hvidkalkede forpagterbolig. Det er egentlig en ret stor bygning, men syner mindre pga. to store lindetræer, der delvis dækker kvisten mod gården. Det 10 fag lange hus med halvvalmet rødt tag, er bygget 1783, sikkert også af Bohlsmann. Facaden har måske også tidligere været smykket med øreliséner, idet der ses rester af sådanne ved husets hjørner.

\section{Augustenborg-stilen}

I forbindelse med denne tidligere omtalte byggeperiode på Augustenborg (1764-76), opførtes samtidigt en række gode borgerhuse i hertugbyen. De var overvejende beregnet som boliger for den voksende skare af hoffolk, og blev nok til dels opført som erstatninger for ældre bindingsværkshuse. Langt de fleste blev bygget i Storegade og ikke i slottets tilkørselsakse, Slotsallé.

I forbindelse med Lorentz Jacobsens byggerier har vi allerede omtalt de to meget rokokoprægede huse, slotspræstegården, Palævej 7, og det mindre Storegade 23. Derudover lægger sig hen ad Storegade en række huse, der kan have hvert deres særpræg, men fælles er den kompositoriske grundtype, som er i en stil, man passende kunne kalde Augustenborg-stilen, idet typen udgik herfra.

Lad os som et eksempel tage Storegade 13, sandsynligvis opført omkring 1770-75 (fig. 17). Det er et grundmuret, hvidkalket hus i 8 fag. Taget er halvvalmet og i rødt tegl. Midterpartiet med en kvist i 3 fag sluttes øverst af med et lille kikvindue. Faginddelingen er dog ikke helt symmetrisk.

Dette er grundtypen, der kan variere i størrelse, være med eller uden øreliséner og have dørparti i rokoko eller Louis Seize, men grundtypen er fælles. Hertugbyen var jo noget for sig i forhold til det omliggende landbrugssamfund på Als. Og på denne tid var disse grundmurede 


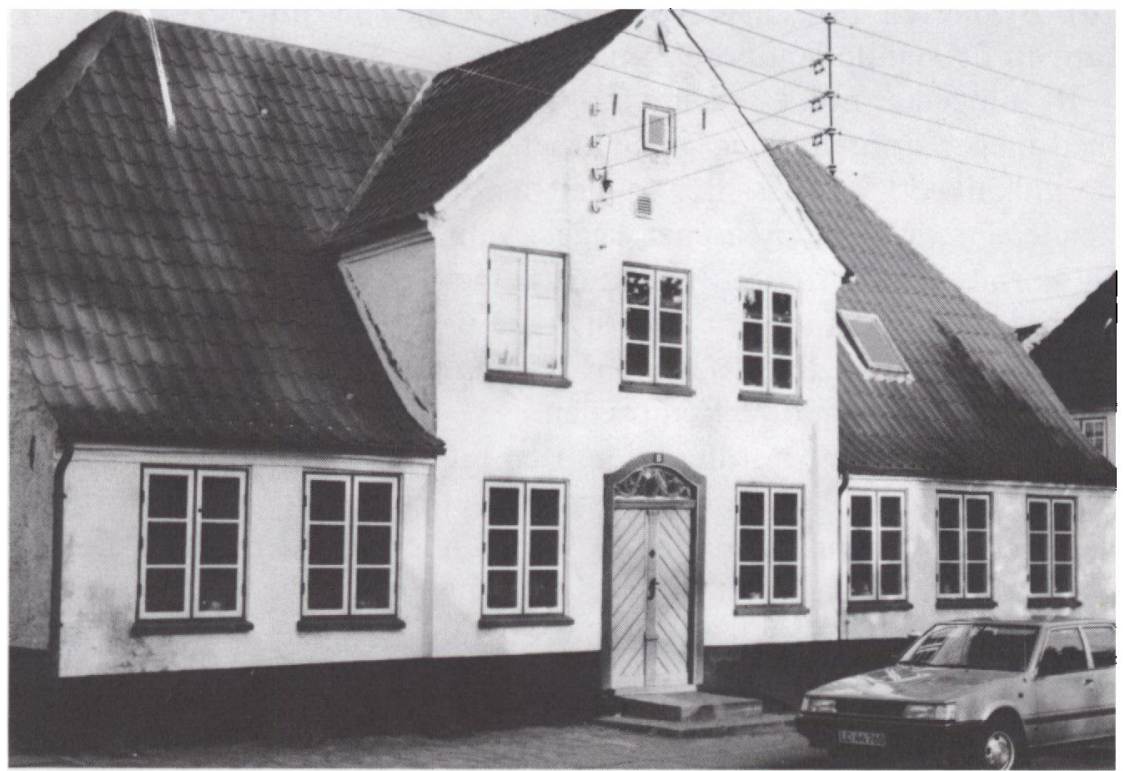

Fig. 17. Det typiske grundmurede Augustenborghus. Storegade 13, Augustenborg, opfort ca. 1770-75.

borgerhuse noget af et særsyn på øen, hvor de fleste huse var $\mathrm{i}$ bindingsværk. Som vi senere skal se, bredte typen sig siden ud over øen; i første omgang blandt de mere velhavende, et tegn på, at det utvivlsomt var forbundet med prestige at få sit hus opført af en hertugelig bygmester.

Man må antage, at i hvert fald alle hoffolkenes huse i Augustenborg er opført af de stedlige hofbygmestre, dvs. Jacobsen og Bohlsmann. Sidstnævnte byggede som nævnt et hus til sig selv, og virkede i byen under hele slotsbyggeriet og tiden efter. Derimod er der intet, der tyder på, at Jacobsen skulle være virksom i byen før 1770. Hans død den 11. januar 1779 i Åbenrå, hvor han boede hele tiden, satte en stopper for flere værker fra hans hånd. Han efterlod sig sin 2. hustru Metta Christina (f. Nissen), som han var blevet gift med i 1762, og to børn..$^{28}$

Det aldste af de tilbageværende Augustenborghuse er det gamle apotek i Slotsallé fra 1761 (senere forlænget med to fag). I samme gade ligger det gamle hospital af en helt anden bygningstype, sandsynligvis opført i 1760'erne.

Af de bevarede huse i Storegade må nr. 7 og 9, begge senere delvis ombygget, nok dateres til ca. 1765-70, ligesom det sjove "Skomagerhus«, nr. 28, fra 1769. 


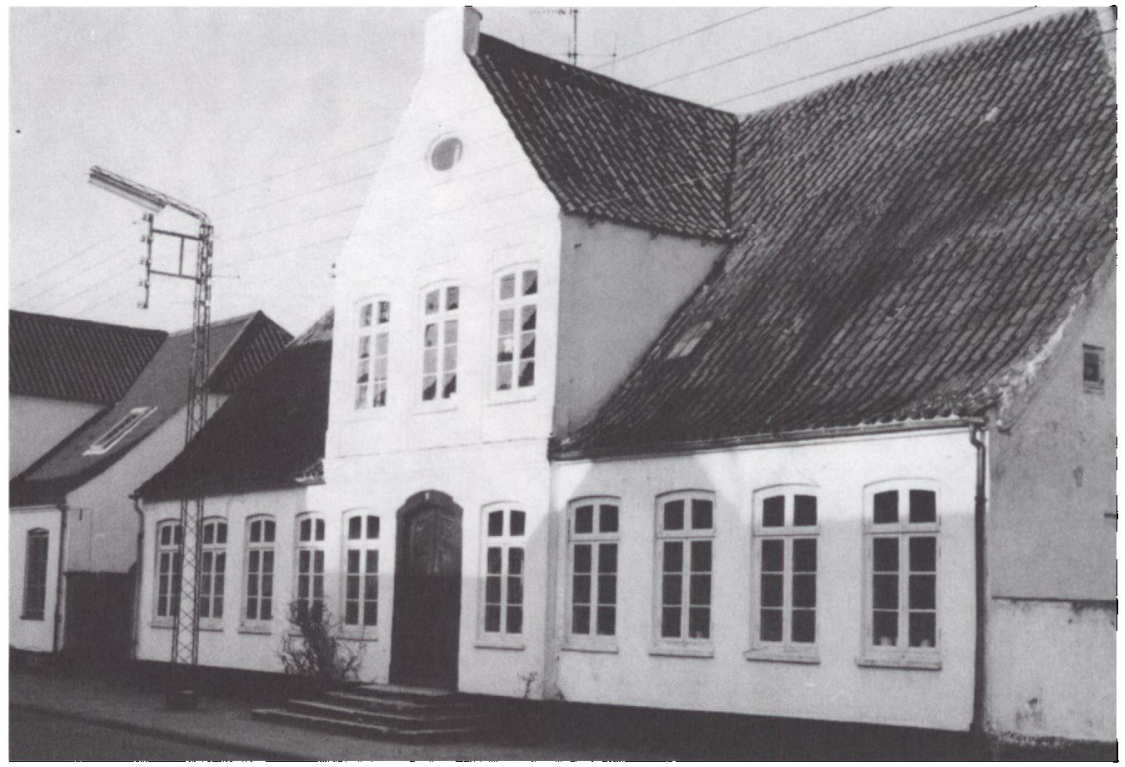

Fig. 18. "Hofradens Hus", Storegade 11, Augustenborg. Dette fine borgerhus er opfort ca. 1775-80, men facaden er andret i 1800-tallet (storre vinduer).

Af de finere huse er foruden nr. 13 og 23, også nr. 11 og 15 opført i 70'erne. Huset Storegade 15 er et eksempel på en mere beskeden udgave (6 fag) af Augustenborg-typen med øreliséner i kvisten. Nr. 11, "Hofrådens Hus«, er et stort og stateligt hus i 11 fag (fig. 18). Ved sin størrelse og sin høje sokkel fremhæver huset sig selv i gaden; men desværre har det ikke længere den originale facade. Hen i 1800-tallet er nye og større vinduer med buet overramme kommet til, ligesom frontispicens øverste afslutning er nyere. Øreliséner er kun bevaret i andet stokværk; men formentlig har de også beklædt hele facaden i stueetagen. ${ }^{29}$

Den gamle skole, nu rådhus, Storegade 20 , fra 1780 , er et ganske godt hus i 9 fag. De små rokokovinduer i frontispicen er af samme type som Storegade 23, og tyder på, at der også i stuen har siddet sådanne vinduer $\mathrm{i}$ stedet for de nuværende større. Over døren ses en hustavle med indskriften "In Gloriam Dei et Salutem Proximi«, Til Guds ære og næstens velfærd. Dørkarmen er ligesom karmene i Storegade nr. 11, 13 og 15 samt Palævej 7, riflet ligesom slottets karme.

De huse i Augustenborg, som er udsmykket med øreliséner, vil jeg antage, at Bohlsmann har bygget. Dels kendes der ikke øreliséner på 


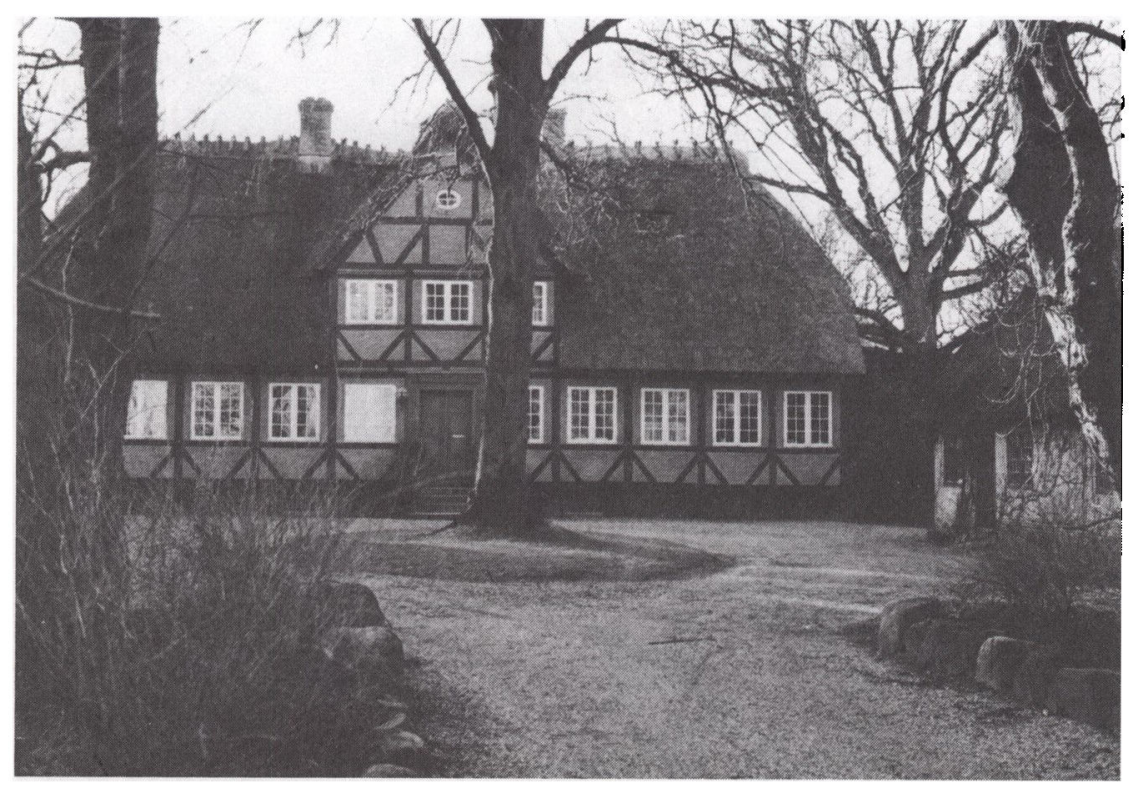

Fig. 19. Horup Prastegård, opfort 1765-69 af bygmester Chr. Aug. Bohlsmann. Det eneste kendte eksempel på Augustenborg-stilen i bindingsvark.

nogle af Jacobsens sikre eller sandsynlige byggerier udover slottet, og dels fortsætter bygninger med disse i mere klassicistiske udgaver i årene efter Jacobsens død.

Et sådant eksempel er det meget stilrene hus Storegade 19, opført 1788. Det er 9 fag langt, heraf de $3 \mathrm{i}$ midterpartiet med frontispicen. Dørpartiet er helt stilren Louis Seize-stil med retvinklet konsolbåret udhæng, hvor rokokoen gerne har buet overkant. Dørfløjene er formet som kannelerede pilastre med de for stilen karakteristiske tandsnitfriser, mæanderborter og ovale former. (Som tidligere antydet er Louis Seize nyklassicismens første fase, og bruges mest som betegnelse for døre og interiører, mens husets eksteriør normalt bliver betegnet som nyklassicisme eller slet og ret klassicisme).

Denne særtype af Augustenborg-stilen, bygger Bohlsmann (sandsynligvis) i 1780'erne og 90'erne flere eksempler på rundt om på Als, dog mest i 11-fagsudgaven sådan som Hofrådens Hus, Storegade 11, oprindeligt har fremstået.

Inden vi kommer så langt, bør vi imidlertid springe lidt tilbage $\mathrm{i}$ tiden for at se på Hørup Præstegård, som stod færdig i 1769 (fig. 19). 
Om dette hus ved vi med sikkerhed, at det er opført af Bohlsmann. ${ }^{30}$ Desuden vides det, at også snedker(mester) Hans Petersen Bleshøy har medvirket. Han virkede samtidigt med Bohlsmann, boede også i Augustenborg og døde samme år som denne, $1794 .^{31}$ De må have arbejdet sammen om mange huse, og det er derfor nærliggende at tro, at denne Bleshøy har stået for de mange fine døre, der fremkom netop i den for egnen rigeste byggeperiode $1770-90$. H. P. Bleshøy var iøvrigt far til den senere hofbygmester J. C. Bleshøy, se senere.

Hørup Præstegård er det eneste eksempel, der er bevaret på Augustenborg-stilen i bindingsværk. Med sit stråtag, gule bindingsværk og skønne beliggenhed, fremtræder præstegården smukt og idyllisk. De $11 \mathrm{fag}$, igen med 3 fag i kvisten, og den høje sokkel, giver huset et fornemt præg. Og det er netop disse gode proportionsforhold, der fremhæver det fornemme i Augustenborg-stilen i forhold til den traditionelle landbostil på Als.

Også på det øvrige Als finder vi som nævnt eksempler på Augustenborg-stilen som både $\mathrm{i}$ tid og stil passer på bygmester Bohlsmann. Mindst 6 bygninger af denne type er bevaret. Den første i tid er Tontoftgård i Nordborgs nordlige udkant. Der er ikke noget direkte vidnesbyrd om opførelsestiden, men stilen tyder på, at huset nok er rejst ca. 1770-75. Herom vidner bl.a. den smukke dør mod haven i fint udskåret rokokomønster, buet overkant og fint overvindue (fig. 20). Taget er stråtækt, og bygningen er kun 10 fag lang, idet midterpartiet symmetrisk deler sig over to fag i modsætning til de følgende bygninger, der alle er i 11 fag. Facaden med øreliséner er pudset, og står nu kalket $i$ en svagt rosa farvetone.

Et lignende hus i Nordborg er Løjtertoft 32 fra 1784, og med 11 fag, heraf 3 i gavlkvisten, er den ligesom de næste 4 bygninger af samme type som Hofrådens Hus, Storegade 11 i Augustenborg. Huset er gulkalket med rødt tegltag, og er på et tidspunkt blevet forhøjet. $\emptyset$ verst i kvisten ses initialerne "JC", vel for bygherrens navn. Den af gamle smedejernsgelændere flankerede indgangsportal, er et interessant eksempel på den stilovergang, som netop fandt sted i opførelsestiden (fig. 21). Således er pilastrene (af jonisk type) og frontonen klart klassicistiske, mens selve dørfløjene er i rokoko i en måske lige lovlig voldsomt malet udgave i hele 5 forskellige farver.

Næste bygning i tid er den tidligere kro i Gammelgård. Den er opført 1785 og hørte da ind under Augustenborg. Hvad skulle derfor være mere naturligt end at lade hertugens bygmester bygge den? Den hvidkalkede bygning havde tidligere stråtag og kvist, men er nu helt 

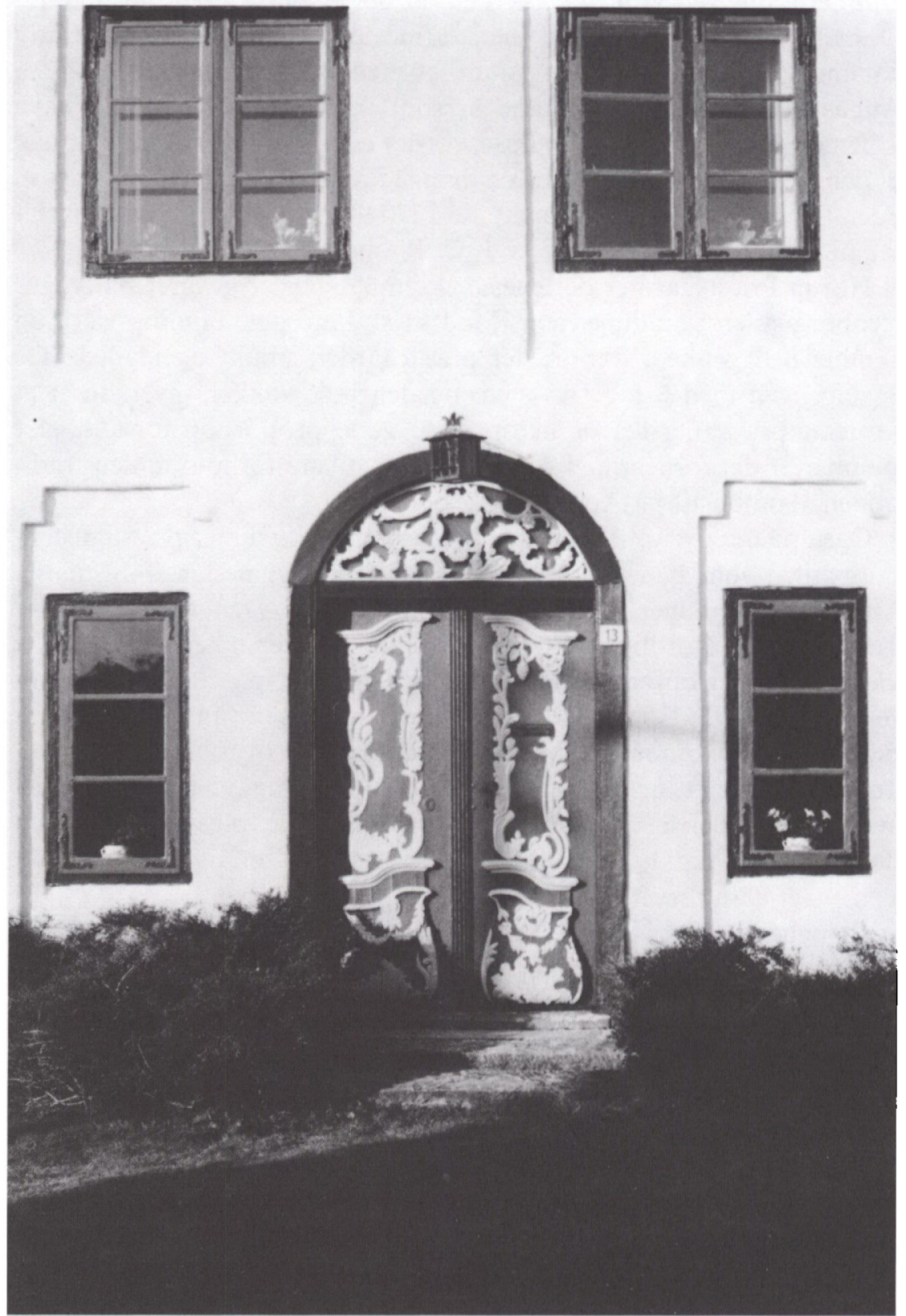

Fig. 20. Fint udskåret rokokoder. Tontoftgård, Nordborg, ca. 1775. 


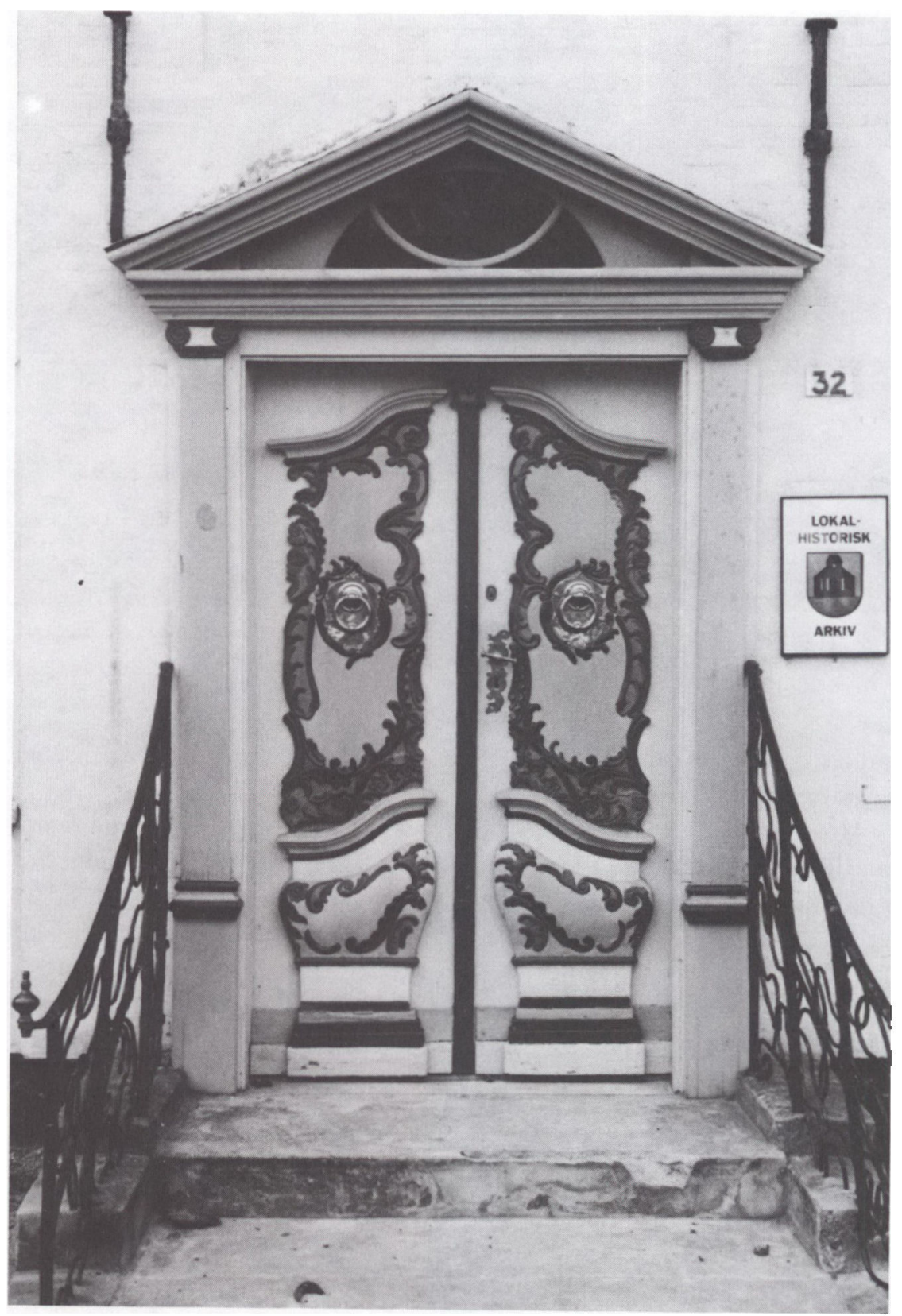

Fig. 21. Stilblanding. Selve doren er rokoko, portalen nyklassicistisk. Lojtertoft 32, Nordborg, 1784. 


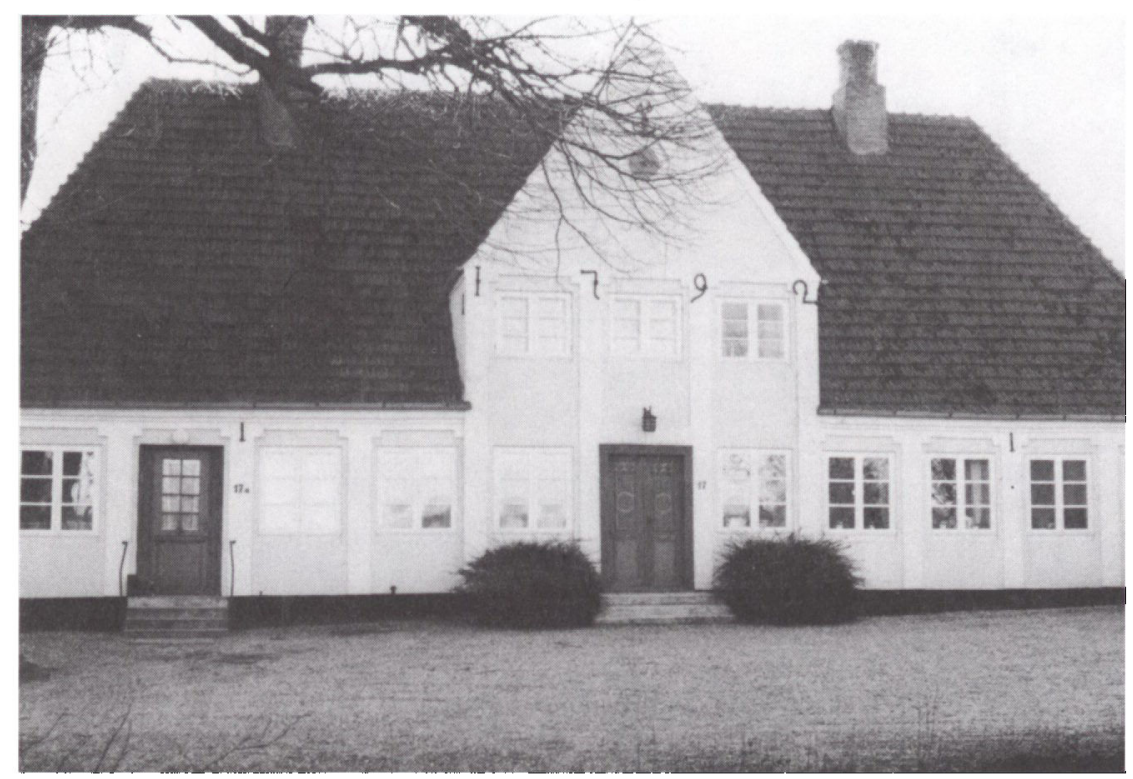

Fig. 22. Et meget smukt og velholdt eksempel pd Augustenborg-stilen. Bemark orelisénerne og Louis Seize-doren. Osterholm, Guderup, opfort 1792.

molesteret, taget omlagt og moderne vinduer og døre indsat. Øreliséner ses dog stadig i stueplanet.

Henholdsvis 1790 og 1792 opførtes stuehusene til de to gårde Bommerlund og Østerholm i Egen Sogn. ${ }^{32}$ De ligger kun få hundrede $m$ fra hinanden, og er af præcis samme type. Mod gårdsiden, paradesiden, er de malet $\mathrm{i}$ en gullig grundfarve, hvorpå de hvide øreliséner står markant frem. Havesiden er mere beskeden uden kvist. Selv om de er af samme type, er de ikke på det seneste behandlet med samme pietet. Hvor Bommerlund har eternittag og forfærdelige moderne døre og vinduer, fremtræder Østerholm mere behageligt. Rødt tegltag, god Louis Seize-dør, og meget velholdt (fig. 22). Grundfarven på Østerholms facade er nærmest beige.

Endelig er der den tidligere bispegård i Ketting. Den er ikke smykket med øreliséner, men da den er ombygget i 1820, kan den have haft dem. Ellers er den af samme grundtype som de øvrige, og bygningstidspunktet ligger nok også omkring 1790 .

Det er forbavsende lidt, man finder af huse i Augustenborg-stilen i områdets største by, Sønderborg, samt på Sundeved. Flere kan være forsvundet $\mathrm{i}$ tidens løb, eller ombygget så meget, at en umiddelbar 
identifikation ikke er mulig. Hvad angår Sønderborg, kan en del huse være bombet sønder i 1864 . Vi finder dog et par eksempler på den beskedne 6-fagstype som Storegade 15 i Augustenborg, i Sønderborg, nemlig bl.a. Slotsgade 15 og Lille Rådhusgade 37 (med øreliséner), begge sikkert opført i perioden 1780-90. I hertugens anden slotsby, Gråsten, er det småt med bevarede huse fra den periode, vi beskæftiger os med, hvilket vel bl.a. hænger sammen med, at næsten alle hoffolkene boede i Augustenborg. Dog bør den af hertug Frederik Christian 1. opførte skole (eller hospital), Skolegade 9, nævnes. Det ganske beskedne hus står i modsætning til de øvrige omtalte bygninger ikke pudset, men blot i gule sten. Huset er bygget i 1783, og over døren ses indskriften "In Gloriam Dei et Salutem Proximi« ligesom på skolen i Augustenborg, der var opført 3 år tidligere.

Inden vi nu forlader bygmester C. A. Bohlsmann og hans bygninger, vil vi runde ham af med et par ord. Han døde 16. februar $1794 \mathrm{i}$ Sønderborg. Dødsårsagen var brystsyge. Og efter dette år er det forbi med nybygninger i den oprindelige Augustenborg-stil. Om Bohlsmann som person vides ikke meget, blot at han ved sin død var hjemmehørende i Sønderborg, at han var gift to gange, og efterlod 3 børn af første ægteskab. Hans første kone, Martha, døde 42 år gammel den 21. november 1786. Den 1. februar giftede han sig igen, denne gang med en enke. ${ }^{33}$

Foruden de her nævnte bygninger, finder vi andre bemærkelsesværdige borgerhuse på egnen, der falder uden for Augustenborg-stilen, og som derfor ikke synes at være opført af hertugens folk. Nævnes bør 3 huse i Sønderborg.

Provstegården, Rosengade 16, er opført 1767 og kunne evt. være opført af Lorentz Jacobsen, men det markante dørparti er ikke tidstypisk, idet det nærmere er barok end den rokoko, vi kender fra Jacobsens bygninger.

På det store borgerhus Perlegade 58, der efter den seneste renovering står gulmalet, står der på facaden årstallet 1704. Tidligere stod der 1604, men efter alt at dømme passer ingen af delene, og huset er nok opført i perioden 1750-70 som også Engquist anfører. ${ }^{34}$ Et af de 8 fag er gjort bredere for at få plads til døren, hvilket må opfattes som en noget ubehjælpsom komposition. Huset er stilmæssigt i slægt med huset Südermarkt 15 i Flensborg fra 1749, der dog er mindre og helt symmetrisk. ${ }^{35}$

Endelig kan nævnes det store to-etages hus Alsgade 16, der også synes at falde uden for Augustenborg-stilen. Det er nu meget forfaldent 
og trænger $\mathrm{i}$ høj grad til en totalrestaurering. Ifølge Trap skulle der på 1. sal være stukkaturer af bdr. Tadei, hvilket imidlertid ikke har kunnet bekræftes til dette arbejde. Huset må dateres til ca. 1780-90.

\section{Nyklassicisme}

Som vi har set, fremstod arkitekturen på Åbenrå-Sønderborg-egnen frem til Lorentz Jacobsens død i 1779 i retninger præget af senbarok og rokoko. Fra 1770'erne og frem til sin død i 1794 byggede C. A. Bohlsmann en række bygninger af et mere moderne præg, dvs. klassicistiske, hvilket ses både $\mathrm{i}$ hovedtrækkene og $\mathrm{i}$ indgangspartierne. Men det er en slags overgangsstil, og endnu ikke rigtig nyklassicisme.

Retter vi blikket udefter, vil vi se, at nyklassicismen allerede omkring 1750-60 er på indtog i Danmark, primært gennem den franske arkitekt N. H. Jardin, der på Kunstakademiet i København underviste den nye generation af arkitekter. Fra 1760'erne arbejdede en række store og mere eller mindre klassicistisk inspirerede arkitekter rundt omkring $i$ Danmark, bl.a. C. F. Harsdorff, G. E. Rosenberg og G. D. Tschierske. Længere nede i Holsten finder vi på denne tid bl.a. arkitekter som Johann Adam Richter (bl.a. herregården Schierensee), C. G. Horn (bl.a. herregårdene Wandsbek og Emkendorf) og senere C. F. Hansen og A. Bundsen. ${ }^{36}$

Disse arkitekter var ajour med stiludviklingen og byggede rundt omkring for store bygherrer. Men som sædvanlig varede det noget, inden stilen trængte igennem blandt provinsielle bygmestre, som dem vi her hovedsageligt beskæftiger os med. Det er derfor vi stadig helt op i 1790'erne finder rokoko i det slesvig-holstenske område. I virkeligheden er stilen på Åbenrå-Sønderborg-egnen faktisk rimeligt ajour med tidens akademiske strømninger $i$ forhold til egne i Holsten, hvor man - især i borgerhuse - helt op i 1790'erne lavede dørpartier i rokoko. ${ }^{37}$

Det første eksempel på en egentlig klassicistisk bygningsopfattelse, finder vi i "Prinsens Hus« i Augustenborg (fig. 23). Bygherren var prinsen selv, nemlig prins Æmil August (1722-86), bror til hertug Frederik Christian 1. I 1764 trak den ugifte prins sig tilbage fra militærtjeneste, og lod derefter sit lille gårdanlæg bygge på det sted, hvor også siden Palæet kom til at ligge. Prinsens Hus er af omfang ret beskedent med 5 brede fag $\mathrm{i}$ to stokværk. Det står nu i al sin enkelhed rødmalet med 4 hvide liséner og valmtag og udstråler trods alt en vis stil. Som Paulsen skriver kan huset tidligst være opført 1765, og senest 1775 hvor betegnelsens »Prinsens Hus« kendes. ${ }^{38}$ Rimeligvis mellem 1765 og 


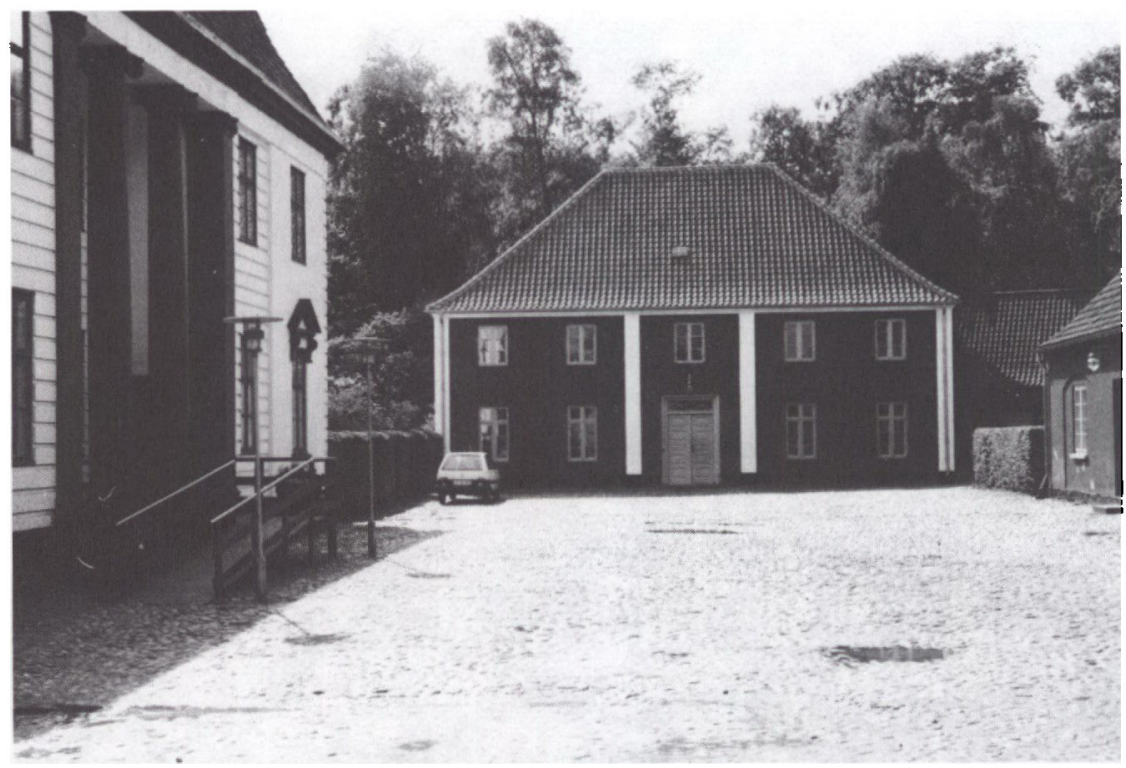

Fig. 23. Prinsens Hus i Augustenborg. En klassicistisk villa opfort af ukendt bygmester ca. 1765-70. Til venstre Paloet.

1770. Arkitekten er ukendt, og ingen af de lokale bygmestre synes umiddelbart at kunne komme på tale.

Prins Æmil August testamenterede sit hus med gårdanlæg til sin niece, prinsesse Louise (1764-1815). Men ved prinsens død i 1786 fandt hans bror hertugen ikke huset tilstrækkeligt til sin datter, og nogle år senere blev Palæet opført som bolig for prinsessen, der her indtil sin død i 1815 holdt eget hof (fig. 24). Siden boede hendes svigerinde, enkehertuginde Louisa Augusta (1771-1843) i Palæet.

Husets bygningshistorie er grundigt beskrevet af Jørgen Paulsen. ${ }^{39}$ Det er tegnet af den københavnske arkitekt Peter Meyn (1749-1808). I sin egenskab af patron for Københavns Universitet kom hertug Frederik Christian 2. i kontakt med Meyn, der for universitetet havde opført Kirurgisk Akademi i Bredgade i 1785-87. Huset er fra Meyns hånd betegnet som et »lyststed «, og er sandsynligvis bygget 1790-91. Det pompøse palæ, hvidt med sorte søjler og pilastre, er et ganske elegant hus og godt beliggende. Imidlertid var det fra Meyns side tænkt endnu fornemmere, idet man kan sammenligne med Meyns originale tegning, der viser et mere udsmykket hus med en anden vindueskomposition. Baggrunden for ændringerne til det kunstnerisk ringere, kender 


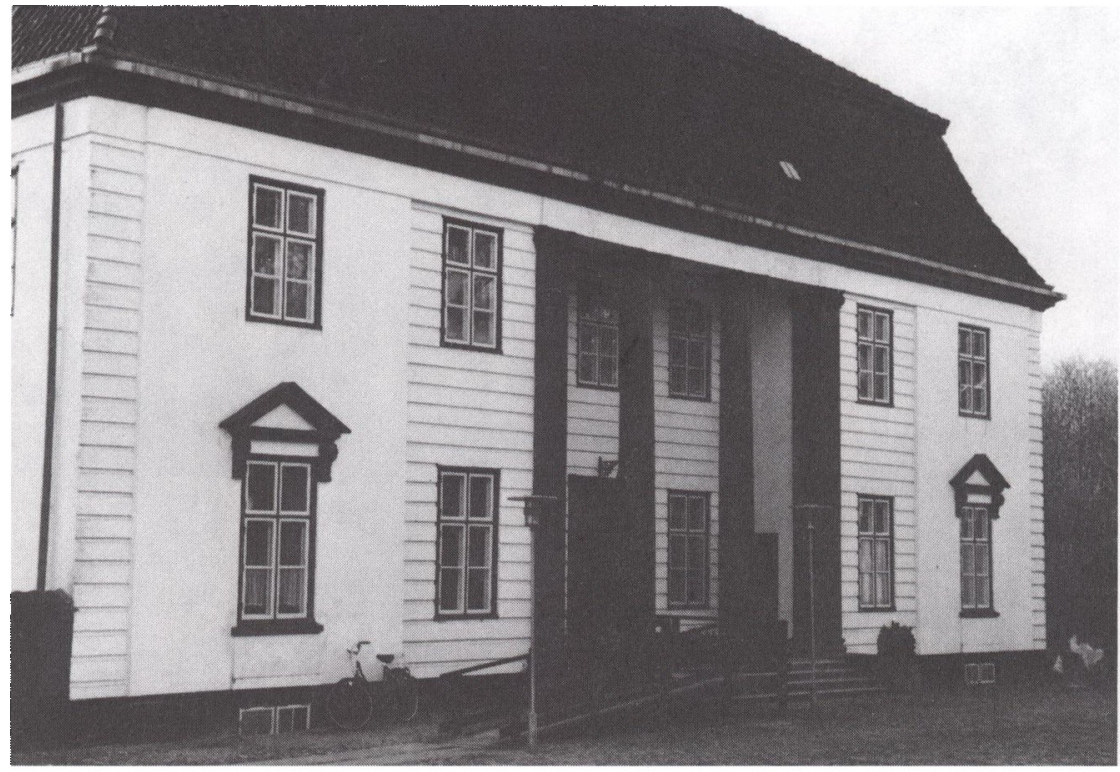

Fig. 24. Palcet i Augustenborg set fra gården. Tegnet af arkitekten Peter Meyn, men andret noget ved opforelsen ca. 1791-92.

vi ikke, men måske har augustenborgernes spartanske arkitektursyn (jvf. slottet) givet sig udslag i ordre til ændringerne af tegningerne før opførelsen. Det har formentlig været bygmester Bohlsmann, der har stået for selve opførelsen af huset, og måske også ændret tegningerne.

Som det står nu, er Palæet dog trods alt et fint klassicistisk bygningsværk i Meyns Harsdorff-inspirerede stil (C. F. Harsdorff var tidens toneangivende arkitekt). Palæet er i 7 fag, to stokværk og med sort mansardtag. Mod gården er indgangspartiet fornemt trukket tilbage bag joniske søjler, mens havefacaden med blik mod Augustenborg Fjord, er udsmykket med pilastre. På hovedfacaderne er murværket fuget på klassicistisk vis, mens gavlene er med øreliséner. Fra Bohlsmanns død i 1794 og frem til 1802 finder vi ikke nogle specielle bygninger af borgerligt eller fornemmere præg i området. Og først efter år 1800 hører vi igen om en hertugelig bygmester, nemlig Jürgen Christian Bleshøy (1773-1826).

Arkitekten C. F. Hansen (1756-1845) beklædte på denne tid embedet som kongelig landbygmester i hertugdømmerne. Han var bosat i Altona, $\mathrm{i}$ hvis omegn han byggede mest. ${ }^{40}$ Fra 1798 knyttedes han løst til Augustenborg som hertugens rådgiver $\mathrm{i}$ bygningsanliggender. ${ }^{41}$ Han 


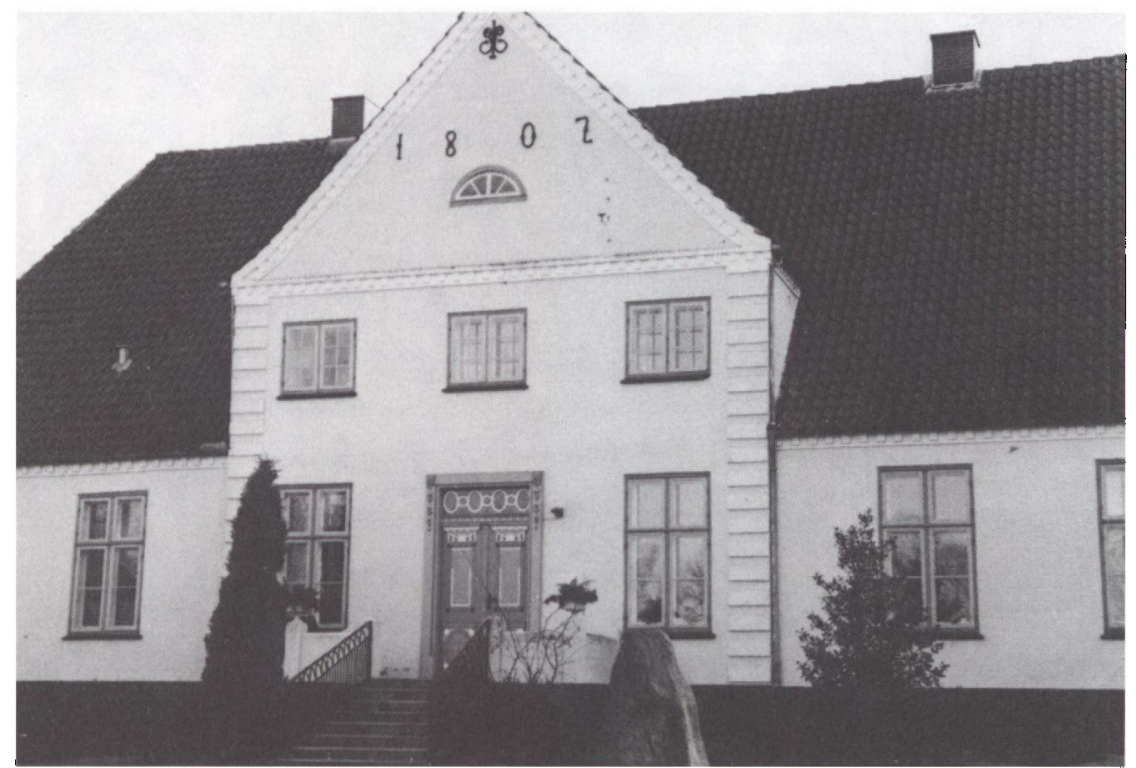

Fig. 25. Ketting Prastegdrd, opfort 1802.

kom her i kontakt med snedkeren J. C. Bleshøy, og tog ham i lære hos sig i nogle år på tegnestuen i Altona. Jürgen Chr. Bleshøy fødtes den 16. november 1773 i Blæsborg nær Ketting som søn af tidligere omtalte snedker Hans Petersen Bleshøy.42 I 1804 blev han officielt udnævnt til hertugelig bygningskonduktør. ${ }^{43}$

Allerede i 1802 blev den nye præstegård i Ketting dog opført i klassicistisk stil til præsten Chr. Aug. Burchardi. Da sognet hørte under hertugens patronat, er det vel rimeligt at antage, at Bleshøy kan have stået for denne bygning, selv om han endnu ikke var udnævnt til bygningskonduktør. Det fine hus ligger i landlige omgivelser, men har karakter af et byhus (fig. 25). Huset er i 7 brede fag, heraf 3 i det høje midterparti. Taget er ligesom Augustenborg-husene 20-30 år før i rødt tegl og halvvalmet. Murværket står nu i en svag rosa farvetone, som fremhæver de hvide kvaderliséner og friserne, der indrammer trekantfrontonen. Vinduesrammerne er malet blå. Den rigt udskårne samtidige Louis Seize-dør er holdt i de samme farver: hvid, rosa og lyseblå (fig. 26).

Den 12. oktober 1805 giftede Bleshøy sig med Maria Friedrichsen. Han benævnes da "Bau-conducteur« og var bosat i Augustenborg. ${ }^{44}$ 


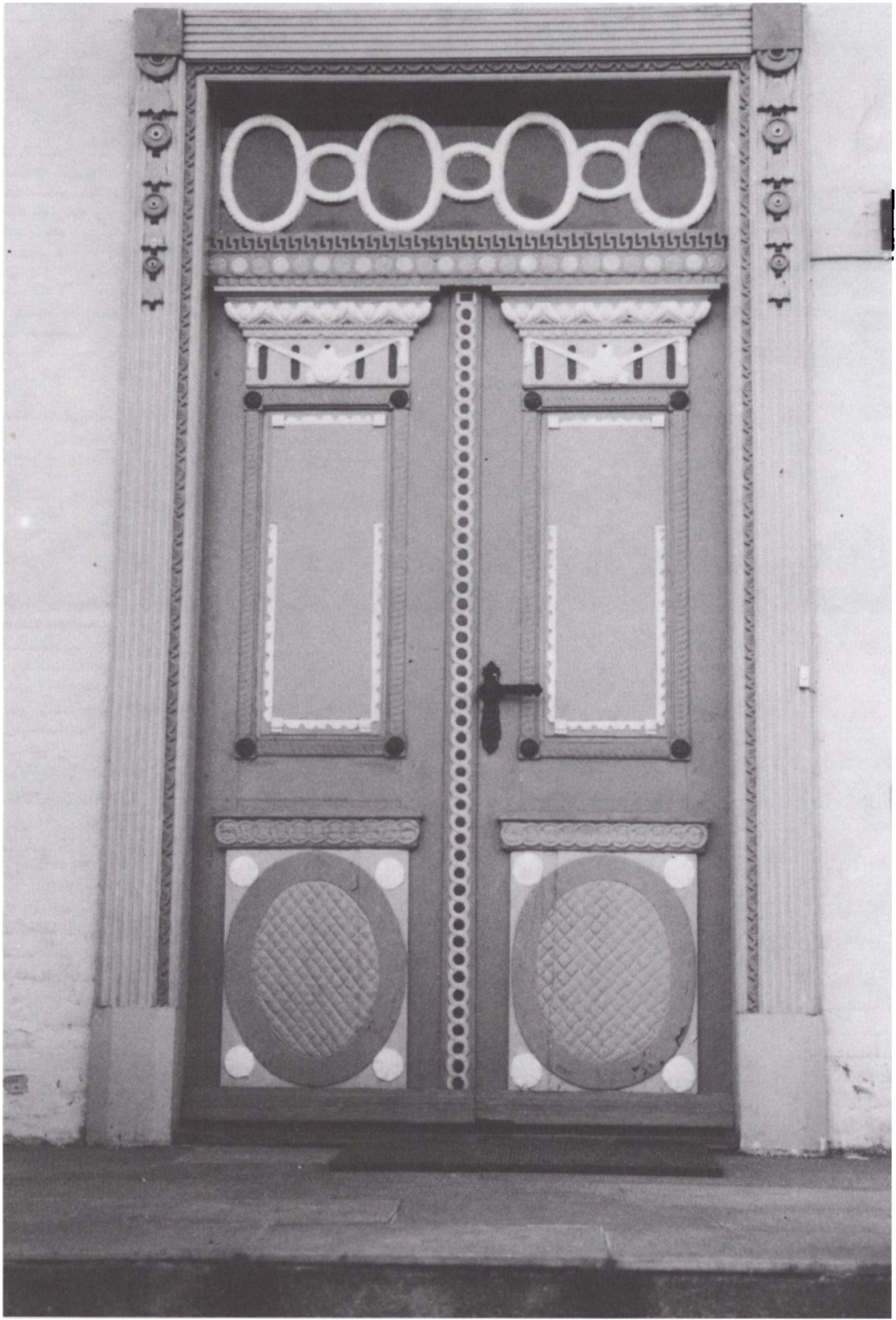

Fig. 26. Ketting Prastegård. Den rigt udskdrne hoveddor viser de fleste nyklassicistiske ornamenter, 1802. 


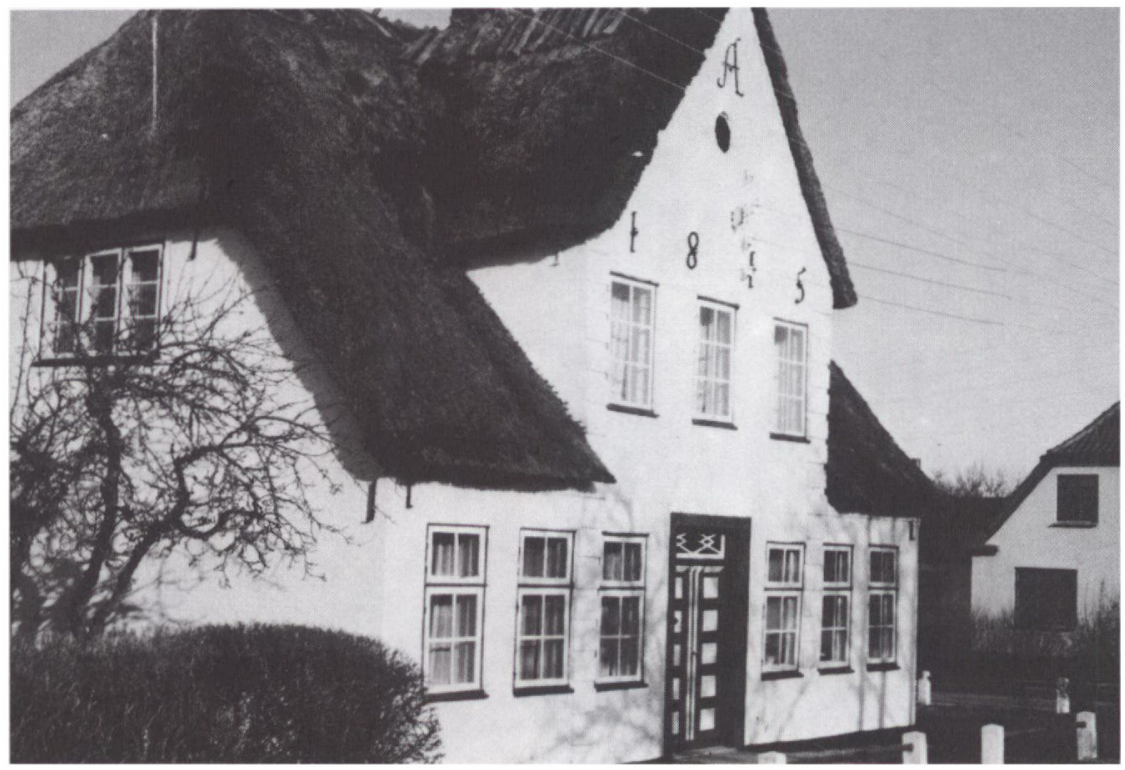

Fig. 27. Det tidligere kapellani i Guderup. Opfort 1815 som en mindre udgave af prastegdrden samme sted, der blev bygget $i 1805$.

Samme år opførtes for præsten Hans Ahlmann Guderup Præstegård. Den er i stil med naboen i Ketting, men er dog mere beskeden og landlig i typen. Fagene er smallere og taget er stråtækt. Midterpartiet er dog på samme måde indrammet af kvaderliséner og de for klassicismen så karakteristiske murstensfriser. Ti år senere, $\mathrm{i} 1815$, byggedes kapellanboligen i Guderup som en charmerende mindre udgave af præstegården samme sted, blot i 5 fag mod præstegårdens 9 (fig. 27). Bleshøy kan vel udmærket have stået for disse bygninger.

I 1807 opførte Bleshøy for hertugen den stilfulde "Kavalérbygning« i Augustenborg (fig. 28). Her er inspirationen fra C. F. Hansen særdeles tydelig. ${ }^{45}$ Huset, der er bygget i en stump vinkel, er størrelsesmæssigt 8 fag langt og to stokværk højt. De to brede hjørnefag er indrammet af forskudte kvaderliséner. Taget var tidligere rødt, men er nu dækket af sortglaseret tegl, hvilket står godt til det ligeledes sorte kælderparti. Det tempelagtige indgangsparti af træ består af brunmalede pilastre og fronton.

Ellers kendes ikke med fuld sikkerhed byggerier af Bleshøy. Men det faldt heller ikke i hans lod at arbejde $i$ en tid med livlig byggeaktivitet. Den store tid på egnen i den henseende var frem til ca. 1790, men 


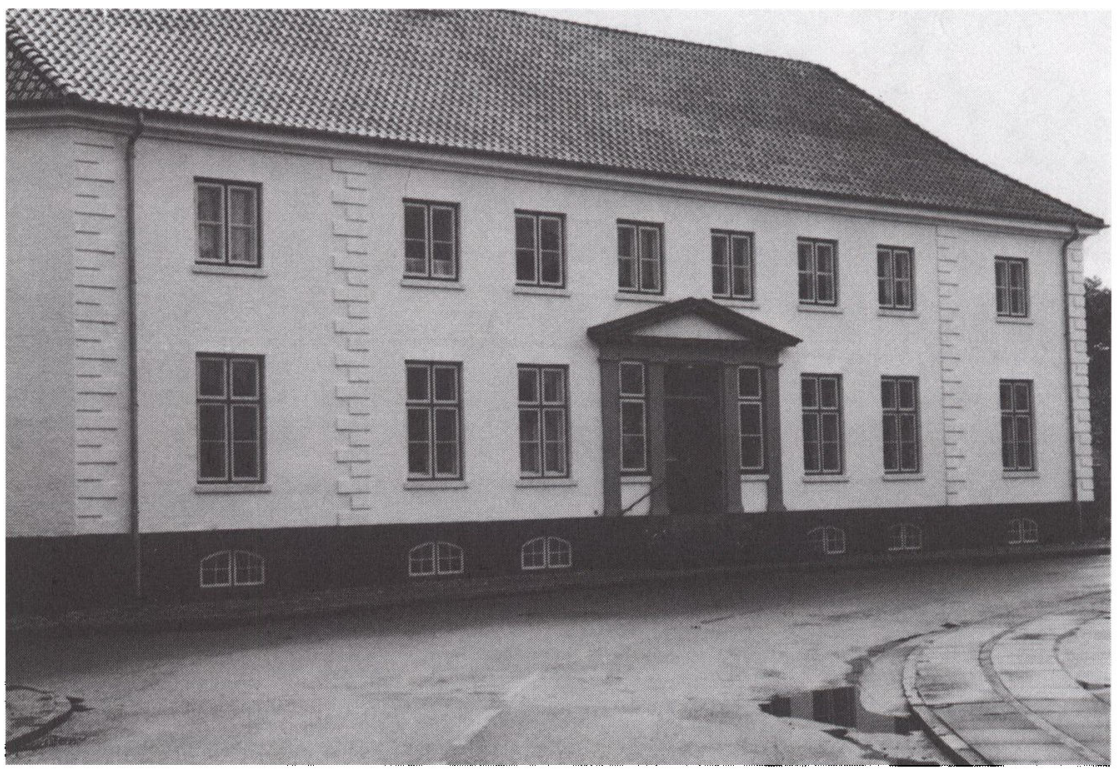

Fig. 28. Den stilfulde "Kavalérbygning« $i$ Augustenborg. Opfort af bygmester Jürgen Chr. Bleshay $i 1807$.

nu først i 1800-tallet var hertugens byggebehov stort set opfyldt, og blandt bønder og borgere var det anderledes knappe tider end før. Napoleonskrigene var i fuld gang og statsbankerotten inden for synsvidde. Han har dog nok haft en del mindre byggerier for hertugen, bl.a. rundt om på de mange gårde, der hørte under Augustenborg. Desuden er stuehuset på Gråsten Ladegård opført i Bleshøys tid, og sikkert opført af ham, men ombygget igen i $1876 .{ }^{46}$

Der er som nævnt ikke mange rigtige klassicistiske bygninger på egnen, men et par stykker kan Bleshøy udmærket have bygget. Det drejer sig først om det lille fine to-etages hus Søndergade 7 i Sønderborg (fig. 29). Huset er i 5 fag, og hjørner og midterparti flankeres af kvaderliséner. Det trænger til en renovering og en opmaling, f.eks. gul grundfarve med hvide liséner. Det må dateres til omkring 1810.

Endelig er der Det gule Palæ i Gråsten, opført 1816 (fig. 30). Det smukke palæ ligger fornemt tilbagetrukket fra vejen. Det er et dybt hus $\mathrm{i}$ to stokværk, 7 fag og høj kælder. Valmtaget er dækket af sort tegl. Den gule facade er symmetrisk opdelt af 4 hvide liséner, og de to yderste fag til hver side har fuget murværk. Bygherren var hofråd og justitiarius for de gråstenske godser Thomas Thomsen. Det er 


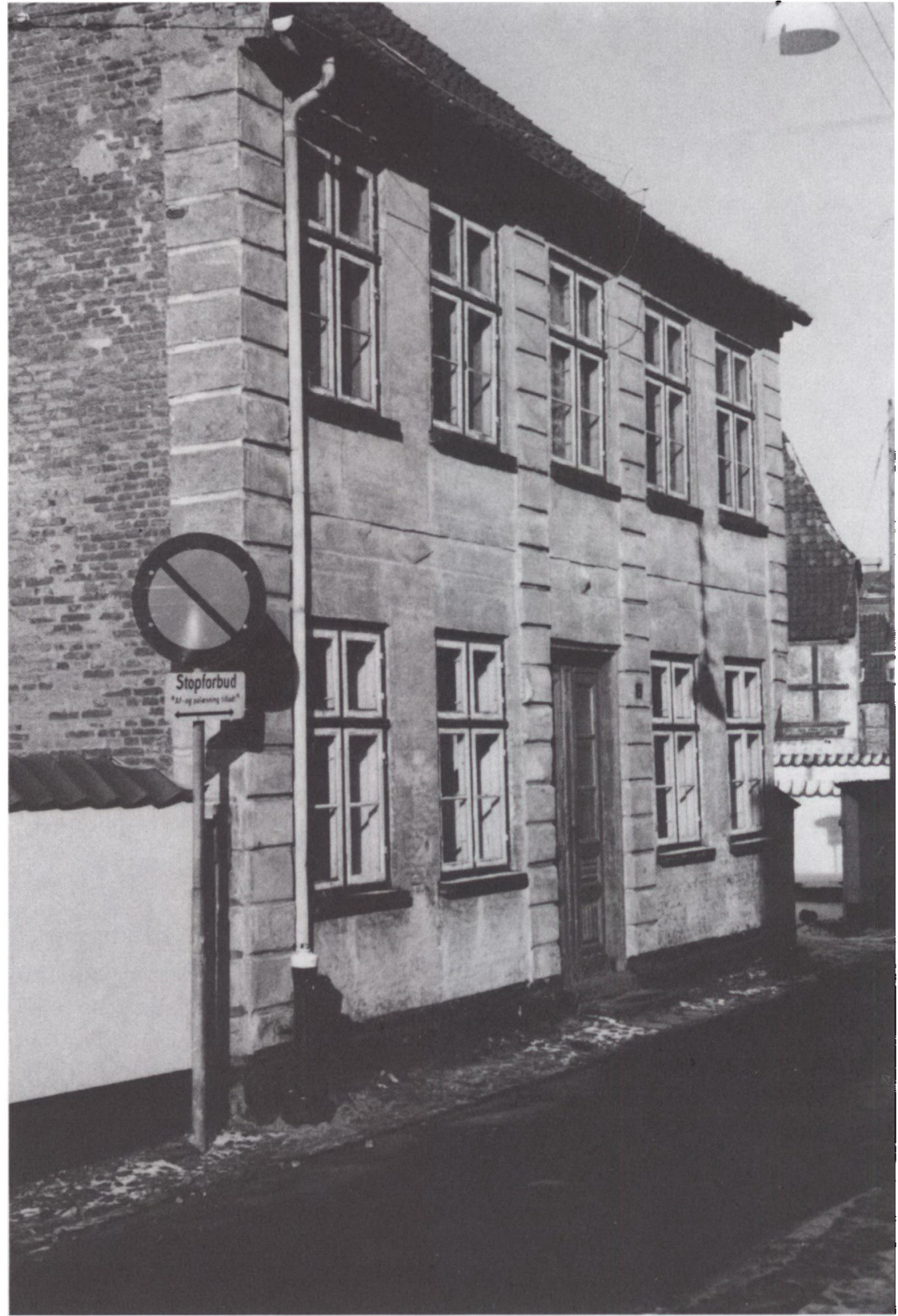

Fig. 29. Et dejligı nyklassicistisk hus med kvaderliséner, Sondergade 7, Sonderborg. Måske opfort af J. C. Bleshoy omkring 1810. 


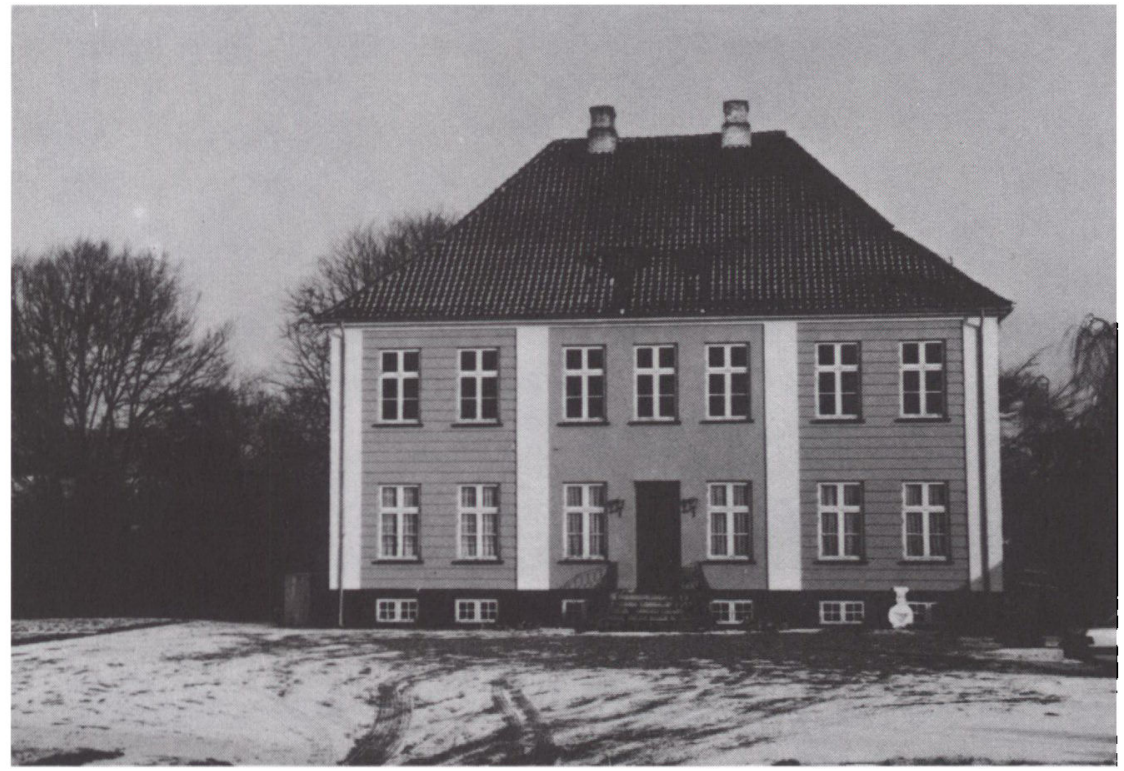

Fig. 30. Det gule Pala, Gråsten. Opfort 1816 for hofråd Thomas Thomsen, sikkert af bygmester Bleshoy.

nærliggende at tro, at han har anvendt godsernes egen bygmester, Bleshøy, til at tegne og opføre hans nye bolig. Det gule Palæ er af samme bygningstype som Prinsens Hus i Augustenborg (blot større), en bygning Bleshøy har kendt fra barnsben af (sammenlign fig. 23 og 30).

Ingen andre bevarede klassicistiske bygninger på egnen kan umiddelbart sættes i forbindelse med Bleshøy, der endte sine dage i Augustenborg den 23. januar 1826, hvor han benævnes "Bau-meister «. ${ }^{47}$

Ingen af de mere kendte arkitekter synes at have arbejdet på egnen her først i 1800-tallet. Dog ombyggede C. F. Hansen Brundlund Slot i Åbenrå i 1806-07, og han stod måske også for nogle facader til borgerhuse i Flensborg, f.eks. Storegade 24 og Holm 13.48 Hans rådhus i Åbenrå blev først opført senere, i 1828-30.49 Langt de fleste af de bygninger, der gjorde $\mathrm{C}$. $\mathrm{F}$. Hansen så berømt, finder man sydligere, $\mathrm{i}$ Holsten.

Blandt flere betydelige arkitekter, der først i 1800-tallet arbejdede i Slesvig-Holsten, bør endvidere fremhæves Axel Bundsen (1768-1832), der foruden Hansen var den, der arbejdede nordligst i hertugdømmerne. Han var lidt yngre end Hansen, men ligesom ham uddannet på 
Kunstakademiet i København. Han stod for en del betydelige byggerier i hertugdømmerne, hvoraf kan fremhæves herregårdene Knoop (ca. 1791-98) og Drült (1806-07). Det nordligste, han byggede, var dog vistnok i Flensborg, hvor han bl.a. opførte huset Angelbogade 2 i 1804 samt kapellet på kirkegården 1812-13.90

\section{Afslutning}

I det foregående har vi behandlet et afgrænset bygnings- og stilhistorisk område. Geografisk er området afgrænset til et område, der svarer til det gamle Åbenrå-Sønderborg Amt fra før sammenlægningen i 1970.

Inden for dette geografiske område finder vi som sagt også et afgrænset stilområde. Dette er på det overordnede plan præget af Danmarks og hertugdømmernes førende arkitekter, men i praksis effektueret af lokale bygmestre uden direkte akademisk skoling. Dette træk må opfattes som ret generelt, og går igen i mange andre lokalområder. Stilområdet på Åbenrå-Sønderborg-egnen er afgrænset således, at en lokal tradition blomstrede i perioden fra omkring 1750 til først i 1800-tallet, sådan som vi har set. Herfra skal man helt til Haderslev-egnen, til de holstensk-frisisk påvirkede marskområder (især Tønder) og syd for grænsen for igen at finde bygningskultur af en sådan kvalitet som i det beskrevne område. Disse områder synes ikke at have haft direkte forbindelser til Åbenrå-Sønderborg-egnen. Derimod kan der være tale om visse stilforbindelser til Erø. Dette hænger sikkert sammen med de administrative forbindelser mellem Als og Erø, idet de slesvigske hertuger tidligere havde Ærø under sig, ligesom Als og Ærø 1819-1864 var et selvstændigt stift eller bispedømme efter tidligere at have hørt under Fyns Stift.

I denne gennemgang af stiludviklingen i perioden 1750-1820, har der vist sig at være et mønster, der passer sammen med 3 betydningsfulde lokale bygmestre. Disse arbejdede alle delvis for hertugen af Augustenborg, og denne by og dens slot er det centrale sted for stiludviklingen fra 1770'erne. Vi har kunnet inddele de fleste eksisterende bygninger af særlig værdi i 3 tids- og stilmæssige grupperinger: rokoko (Jacobsens tid), overgangsstil/Augustenborg-stil (Bohlsmanns tid) og nyklassicisme (Bleshøys tid).

På denne baggrund (stil, tid og sted) har vi tilskrevet disse bygmestre en række bygninger, når vi ikke havde sikre oplysninger om, hvem ophavsmanden var. Blandt disse er nogle selvsagt mere åbenbare end andre. Desuden er der omtalt andre bygninger af borgerligt præg, som stilmæssigt falder uden for vore 3 bygmestres arbejder. Disse skyldes 
ukendte, udefra kommende folk, eller evt. ukendte lokale. Man må dog grundlæggende gå ud fra, at hertugens bygmestre var dé bedste i området.

Man kunne spørge, hvad der gjorde, at disse 3 håndværksmestre fremhævede sig i forhold til de "almindelige« bygmestre. Vi ved, at Bleshøy blev uddannet hos C. F. Hansen; men for Jacobsens og Bohlsmanns vedkommende kunne man tænke sig, at de efter læretiden har været på valsen rundt om i Danmark eller det øvrige Europa, her har arbejdet sammen med større akademiske arkitekter og på den måde har lært sig en mere kunstnerisk bygningsopfattelse. Endvidere var det på den tid almindeligt, at man brugte bøger med vejledninger $\mathrm{i}$ komposition, udsmykninger med ornamenter m.m.

For en del af de omtalte bygninger galder, at de er fredet. Dette er dog ikke altid en garanti for, at de er velholdt. Man må håbe, at såvel privatpersoner som ejere og forvaltere som myndigheder fremover vil værne om denne egnsprægede og karaktérfulde borgerlige bygningskultur og udvise pietet og respekt over for husene og deres ånd.

\section{HENVISNINGER OG NOTER}

Forfatteren vil gerne takke de bygningsejere og -forvaltere, der velvilligt har givet adgang til bygningerne. En særlig tak rettes til arkivar Lars N. Henningsen, Åbenrå, for råd og vejledning, samt til cand.mag. Michael Flintholm, Århus, for kritiske kommentarer til manuskriptet.

1. Ensted Kirkebog, Landsarkivet i Åbenrå.

2. M. Kamphövener: Borgerskaber i Åbenrå 1686-1867, Åbenrå 1974, p. 40 samt Åbenrå Kirkebog, Landsarkivet i Åbenrå.

3. F. Jerk: Gamle danske Præstegårde, 1978, p. 262. Ensted Kirkebog Aa 2, p. 119, Landsarkivet i Åbenrå.

4. Ensted Kirkebog, note 3, citeret hos Jørgen Paulsen: Augustenborg, 1981, og hos Lars N. Henningsen: Lorentz Jacobsen, Augustenborg Slots bygmester, i: Festskrift til Hans H. Worsøe, Landsarkivet i Åbenrå, 1982.

5. A. Steensberg: Gamle danske Bøndergårde, 1978.

6. Se Henningsen, note 4 samt Danmarks Kirker (bd. 22), Nationalmuseet 1959.

7. L. Jacobsen kan også udmærket have stået for en del andre huse i Åbenrå fra tiden, f.eks. det i 1765-66 opførte Slotsgade 24, men senere ombygget to gange. Vedr. Postholdergården og andre huse i byen se H. H. Engquist: Historiske huse i Åbenrå, 1975.

8. F. Jerk: Herregårde i Danmark. Jylland, 1980. J. Hvidtfeldt i: Roussell: Danske slotte og herregårde, bd. 16, 1967, p. 115ff.

9. Se note 4 og Roussell, note 8, p. 149-52. 
10. Se Henningsen, note 4.

11. Som note 4 .

12. Se Paulsen, note 4, p. 62-65 og Jerk, note 3, p. 292-94.

13. Se Roussell, note 8, p. 153-74.

14. Biografiske oplysninger om mere kendte arkitekter er mest taget fra Weilbachs Kunstnerleksikon bd. 1-3, Aschehoug Dansk Forlag, Kbh. 1949-52.

15. Se også H. P. Clausen \& J. Paulsen: Augustenborgerne. - Historisk Samfund for Als og Sundeved 1980, p. 161-66.

16. Se Paulsen, note 4 , p. $12 \mathrm{ff}$.

17. Se Paulsen, note 4, p. 17ff. og Jerk, i: Sønderjylland. Gyldendals Egnsbeskrivelser, Kbh. 1971, p. 138ff.

18. P. Hirschfeld: Herrenhäuser und Schlösser in Schleswig-Holstein. - Deutscher Kunstverlag, 5. udg., München und Berlin 1980, p. $163 \mathrm{ff}$.

19. Paulsen, note 4, p. 24.

20. Se Hirschfeld, note 18 , p. $196 \mathrm{ff}$., Paulsen, note 4 , p. 30-31, H. v. Rumohr: Danske slotte og herregårde bd. 20, Syd for grænsen 1968 (flere steder) samt G. Benzon: Gamle danske vægbeklædninger. - Kreditforeningen Danmark, 1983, p. $141 \mathrm{ff}$.

21. Danmarks Kirker, bd. 23. - Nationalmuseet, 1961.

22. Paulsen, note 4, p. 29.

23. Desuden refereret hos Paulsen, note 4, p. $27-28$.

24. Som note 23 samt H. Lind: Augustenborg som det var engang. Egernsund 1970, p. 51.

25. Paulsen, note 4, p. 22.

26. Paulsen, note 4, p. 53.

27. Se Roussell, note 8, p. $141 \mathrm{ff}$.

28. Åbenrå Kirkebog, Landsarkivet i Åbenrå.

29. For yderligere oplysninger om husene i Storegade, Augustenborg se: Paulsen, note 4, p. 49ff, Lind, note 24 samt $H$. Lind: De go'e gamle dage i Augustenborg Kommune, Egernsund 1972.

30. Jerk, note 3, p. 268. For øvrige oplysninger i artiklen om præstegårde, se Jerk samt J. Slettebo: Præstegårde på Als og Sundeved, Fra Als og Sundeved, hæfte 45, 1966.

31. Augustenborg Kirkebog, Landsarkivet i Åbenrå.

32. Vedr. disse gamle huse og andre på Nordals, se foruden Trap Danmark, 1967, K. Gottlob: Værn af smukke danske huse af bygningskulturel værdi, bd. 8. Nordals. Fonden for Bygnings- og Landskabskultur, 1972.

33. Sønderborg Kirkebog, Landsarkivet i Åbenrå.

34. H. H. Engquist: Sønderjyske byer. - Gjellerups Forlag, Kbh. 1967, p. 61.

35. Fr. Stender: Das Bürgerhaus in Schleswig-Holstein, Tübingen 1971. A. Kamphausen: Bürgerhäuser in Nordelbingen, Heide in Holstein 1979.

36. Se Hirschfeld, note 18.

37. Som note 35 .

38. Paulsen, note 4 , p. 39 ff.

39. Paulsen, note 4 , p. $42 \mathrm{ff}$.

40. C. M. Smidt: Arkitekten C. F. Hansen og hans bygninger, 1911. W. Jakstein: Christian Friedrich Hansen. Der nordische Klassizist. Karl Wachholtz Verlag, Neumünster 1937.

41. Se note 15, p. 156. 
42. Ketting Kirkebog, Landsarkivet i Åbenrå.

43. Som note 41 .

44. Augustenborg Kirkebog, Landsarkivet i Åbenrå.

45. Som note 41 .

46. Året for opførelsen vides ikke nøjagtigt, se i øvrigt Trap.

47. Augustenborg Kirkebog, Landsarkivet i Åbenrå.

48. Disse kan dog også være opført af Axel Bundsen, se i øvrigt Stender og Kamphausen, note 35 .

49. Se Engquist, note 7, p. 100.

50. Se Hirschfeld, note 18 samt Henning von Rumohr, note 20. Endvidere note 48 . 
Kronologisk oversigt over bygninger af borgerligt prag pd Abenrd-Sonderborg-egnen ca. 1750-1820. Bygningerne er omtalt i artiklen. Parentes omkring bygmestrenes navn betyder, at bestemmelsen ikke er sikker, men mere eller mindre sandsynlig.

\begin{tabular}{|c|c|c|c|}
\hline opført & evt. navn, beliggenhed & evt. bemærkninger & bygmester \\
\hline 1747 & Kliplev Præstegård & & L. Jacobsen \\
\hline ca. 1750 & Morks Kro, Kliplev & kvist tilføjet 1852 & L. Jacobsen \\
\hline ca. $1750-70$ & $\begin{array}{l}\text { Perlegade 58, Sønder- } \\
\text { borg }\end{array}$ & $\begin{array}{l}\text { murankre m. årstallet } \\
1704 \text {, utvivlsomt for- } \\
\text { kert }\end{array}$ & $?$ \\
\hline $1758-59$ & Gråsten Slot & delvis genopbygget & J. G. Rosenberg \\
\hline 1758 & $\begin{array}{l}\text { Postholdergården, } \\
\text { Søndergade 20, } \\
\text { Åbenrå }\end{array}$ & & L. Jacobsen \\
\hline 1761 & $\begin{array}{l}\text { Det gl. Apotek, Slots- } \\
\text { allé, Augustenborg }\end{array}$ & senere forlænget & $?$ \\
\hline $1763-65$ & $\begin{array}{l}\text { Skovbølgård, Gl. } \\
\text { Skovbøl }\end{array}$ & & L. Jacobsen \\
\hline 1766 & $\begin{array}{l}\text { Nymøllevej 28, } \\
\text { Ábenrå }\end{array}$ & senere ombygget & (L. Jacobsen) \\
\hline 1767 & Slotsgade 14, Ábenrå & & (L. Jacobsen) \\
\hline 1767 & $\begin{array}{l}\text { Provstegården, Ro- } \\
\text { sengade 16, Sønder- } \\
\text { borg }\end{array}$ & & $?$ \\
\hline $1765-69$ & Hørup Præstegård & & C. A. Bohlsmann \\
\hline $1765-70$ & $\begin{array}{l}\text { "Prinsens Hus«, } \\
\text { Augustenborg }\end{array}$ & & $?$ \\
\hline ca. $1765-70$ & $\begin{array}{l}\text { Storegade 7, Augu- } \\
\text { stenborg }\end{array}$ & Senere ombygning & $?$ \\
\hline do. & $\begin{array}{l}\text { Storegade 9, Augu- } \\
\text { stenborg }\end{array}$ & do. & $?$ \\
\hline $1764-69$ & $\begin{array}{l}\text { staldgård, porthus, } \\
\text { køkken m.m., Augu- } \\
\text { stenborg Slot }\end{array}$ & $\begin{array}{l}\text { sydl. længe opført } \\
1733\end{array}$ & (J. G. Rosenberg) \\
\hline $1770-76$ & Augustenborg Slot & & $\begin{array}{l}\text { (J. G. Rosenberg og } \\
\text { L. Jacobsen) }\end{array}$ \\
\hline 1770 & Slotsgade 29, Åbenrå & & (L. Jacobsen) \\
\hline 1770 & $\begin{array}{l}\text { Tummelsbjerg, Rin- } \\
\text { kenæs }\end{array}$ & senere ombygget & L. Jacobsen \\
\hline 1771 & Ballegård, Blans & & L. Jacobsen \\
\hline ca. 1775 & $\begin{array}{l}\text { Tontoftegård, Nord- } \\
\text { borg }\end{array}$ & & (C. A. Bohlsmann) \\
\hline ca. $1770-75$ & $\begin{array}{l}\text { Storegade 13, Augu- } \\
\text { stenborg }\end{array}$ & & $\begin{array}{l}\text { (L. Jacobsen eller C. } \\
\text { A. Bohlsmann) }\end{array}$ \\
\hline ca. 1775 & $\begin{array}{l}\text { Storegade 23, Augu- } \\
\text { stenborg }\end{array}$ & & (L. Jacobsen) \\
\hline ca. $1775-80$ & Storegade 15, do. & & (C. A. Bohlsmann) \\
\hline ca. $1775-80$ & Storegade 11, do. & facade sen. ændret & (C. A. Bohlsmann) \\
\hline
\end{tabular}




\begin{tabular}{|c|c|c|c|}
\hline opført & evt. navn, beliggenhed & evt. bemærkninger & bygmester \\
\hline 1776 & $\begin{array}{l}\text { Tidl. slotspræstegård, } \\
\text { Augustenborg }\end{array}$ & & (L. Jacobsen) \\
\hline 1780 & $\begin{array}{l}\text { Storegade 20, Augu- } \\
\text { stenborg }\end{array}$ & tidl. skole & (C. A. Bohlsmann) \\
\hline $1780-90$ & $\begin{array}{l}\text { Slotsgade 15, Sønder- } \\
\text { borg }\end{array}$ & & (C. A. Bohlsmann) \\
\hline $1780-90$ & $\begin{array}{l}\text { L. Rådhusgade 37, } \\
\text { Sønderborg }\end{array}$ & & (C. A. Bohlsmann) \\
\hline ca. $1780-90$ & $\begin{array}{l}\text { Alsgade 16, Sønder- } \\
\text { borg }\end{array}$ & meget forfaldent & $?$ \\
\hline 1782 & $\begin{array}{l}\text { Benniksgård, Rin- } \\
\text { kenæs }\end{array}$ & senere ombygget & $?$ \\
\hline 1783 & Skolegade 9 , Gråsten & tidl. skole & (C. A. Bohlsmann) \\
\hline 1783 & $\begin{array}{l}\text { Forpagterbolig, Sand- } \\
\text { bjerg }\end{array}$ & & (C. A. Bohlsmann) \\
\hline 1784 & $\begin{array}{l}\text { Løjtertoft 32, Nord- } \\
\text { borg }\end{array}$ & senere forhøjet & (C. A. Bohlsmann) \\
\hline 1785 & $\begin{array}{l}\text { Tidl. kro, Gammel- } \\
\text { gård }\end{array}$ & senere ombygget & (C. A. Bohlsmann) \\
\hline 1787 & Felsted Præstegård & & $?$ \\
\hline $1787-88$ & $\begin{array}{l}\text { Hovedbygn., Sand- } \\
\text { bjerg }\end{array}$ & & C. A. Bohlsmann \\
\hline 1788 & $\begin{array}{l}\text { Storegade 19, Augu- } \\
\text { stenborg }\end{array}$ & & (C. A. Bohlsmann) \\
\hline ca. 1790 & $\begin{array}{l}\text { Tidl, bispegård, Ket- } \\
\text { ting }\end{array}$ & ombygget 1820 & (C. A. Bohlsmann) \\
\hline 1790 & $\begin{array}{l}\text { Bommerlund, Gu- } \\
\text { derup }\end{array}$ & & (C. A. Bohlsmann) \\
\hline ca. $1791-92$ & Palæet, Augustenborg & andret v. opfør. & P. Meyn \\
\hline 1792 & Østerholm, Guderup & & (C. A. Bohlsmann) \\
\hline 1802 & Ketting Præstegård & & (J. C. Bleshøy) \\
\hline 1805 & Guderup Præstegård & & (J. C. Bleshøy) \\
\hline 1807 & $\begin{array}{l}\text { Kavalérbygning, Au- } \\
\text { gustenborg }\end{array}$ & & J. C. Bleshøy \\
\hline ca. 1810 & $\begin{array}{l}\text { Søndergade 7, Søn- } \\
\text { derborg }\end{array}$ & & (J. C. Bleshøy) \\
\hline 1815 & $\begin{array}{l}\text { Kapellanbolig, Gu- } \\
\text { derup }\end{array}$ & & (J. C. Bleshøy) \\
\hline 1816 & $\begin{array}{l}\text { Det gule Palæ, Grå- } \\
\text { sten }\end{array}$ & & (J. C. Bleshøy) \\
\hline $1828-30$ & Rådhuset, Åbenrå & & C. F. Hansen \\
\hline
\end{tabular}

